مقايسه روش محلولياشى و مصرف خاكى آهن بر ويزّى فيزيولوزيكى - بيوشيميايى و آهن فعال گياه يونجه يكساله (Medicago scutellata L.) در مقادير مختلف آهك در خاك

$$
\text { زهرا قشلاقى '، رضا خراسانى بّ، محمد كافى و امير فتوت }
$$

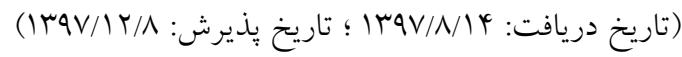

جكيده

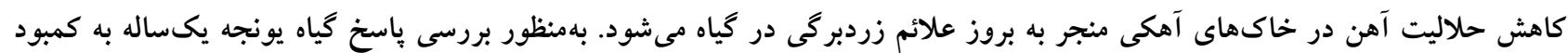

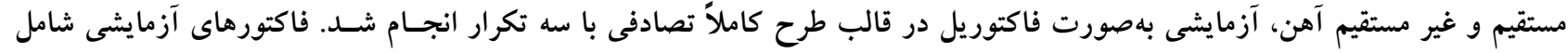

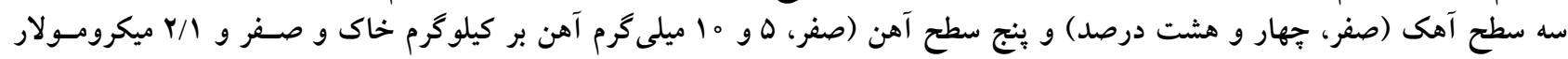

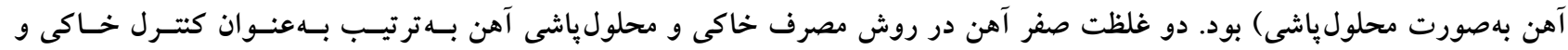

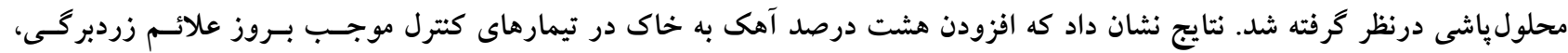

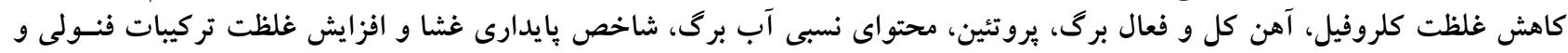

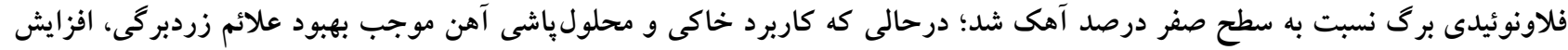

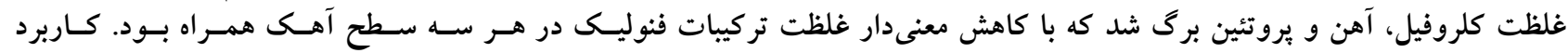

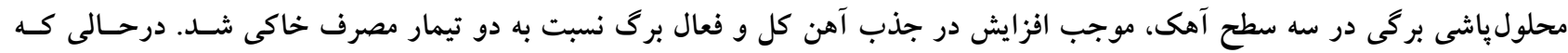

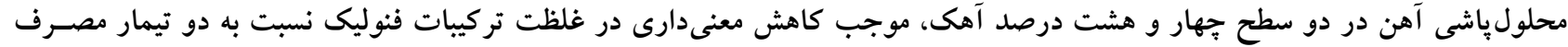

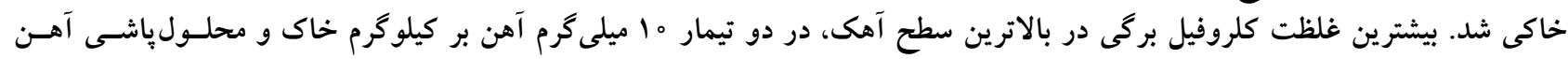

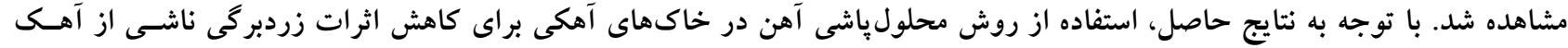

توصيه مىشود.

وازههاى كليدى: تركيبات فنولى و فلاونوئيدى، زردبرگى، كربنات كلسيم، Fe-EDDHA

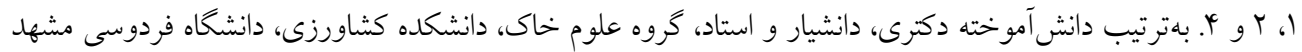

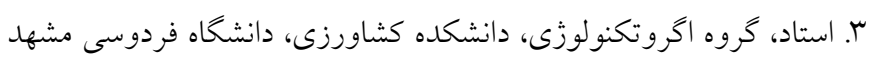

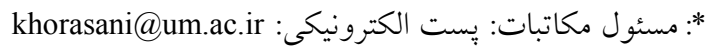


كاملاً مشخص نيست كـه ايـن دو علائسم كـاملاً معـادل يكـديكر مقدمه

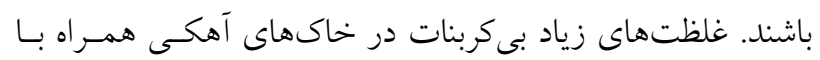
pH

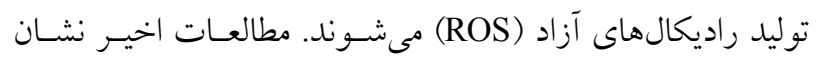

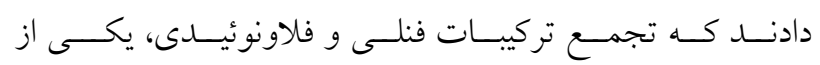

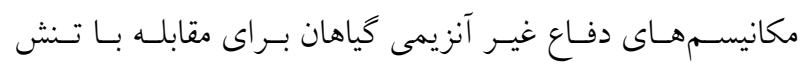

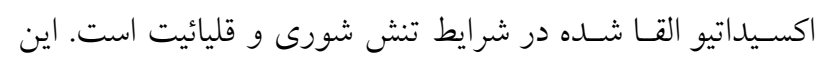

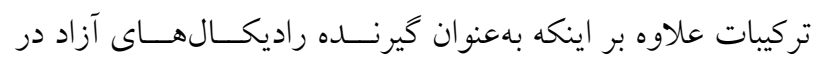

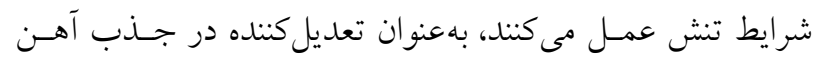

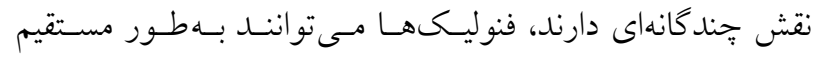

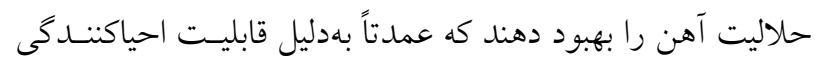

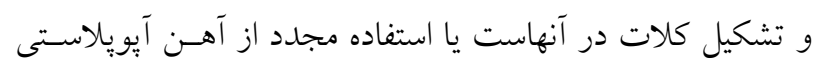

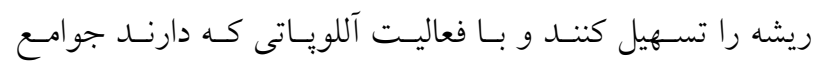
ميكروبى ريزوسفر را تحت تأثير قرار دهند تا به توليد سـيدروفور و آكسين بيردازند (rV).

كياهان مختلف در حساسيت و مقاومت خود به كمبود آهن متفاوت هستند. تنوع در توانايى جذب و انتقال آهن در كيـاه در درد

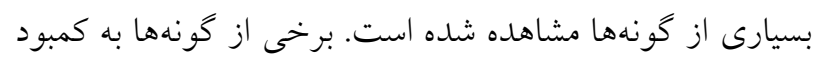

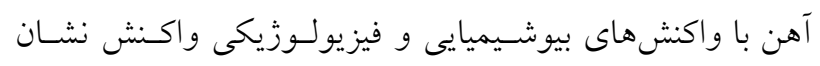

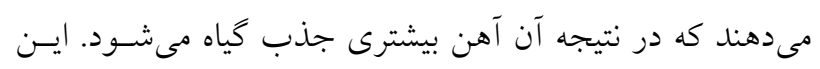

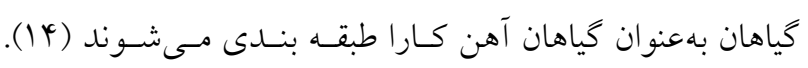

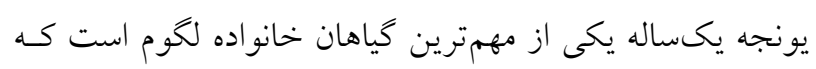

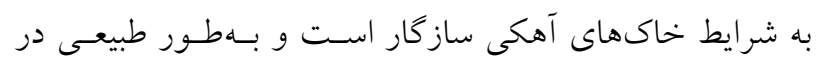

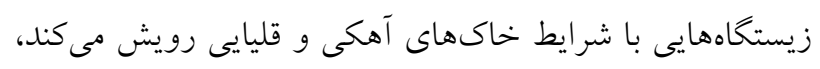

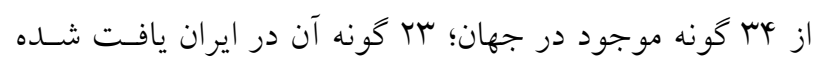

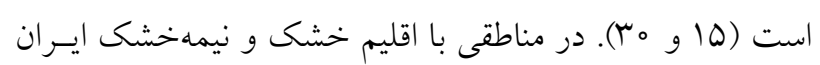

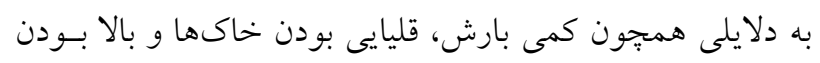

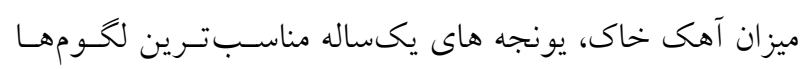

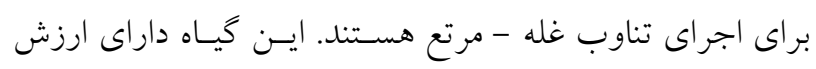

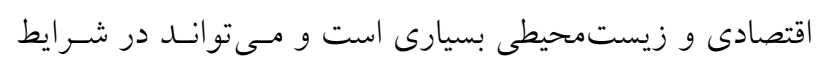

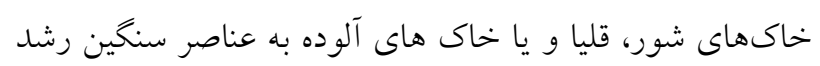

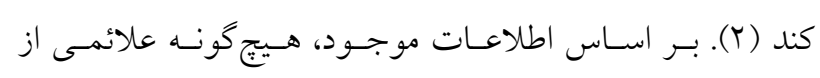
آهن يكى از فراوانترين عناصر در يوستهـ كـره زمسين محسـوب

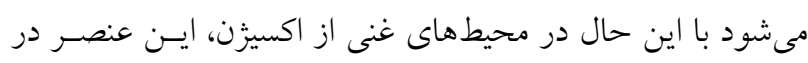

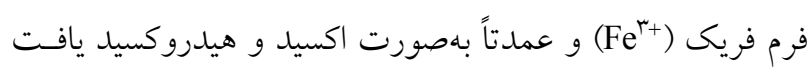

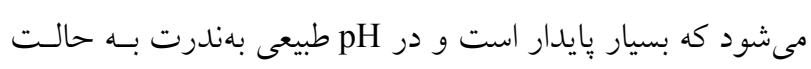

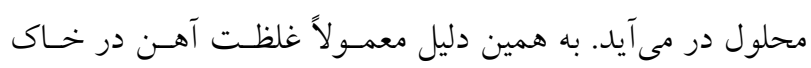

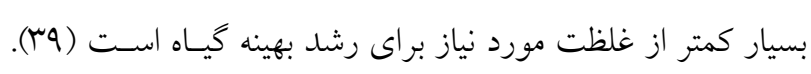

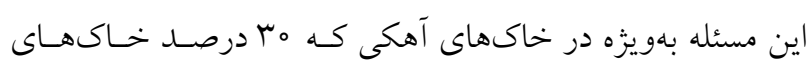

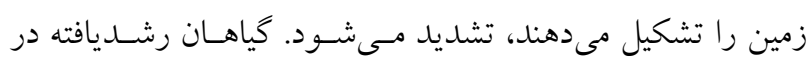

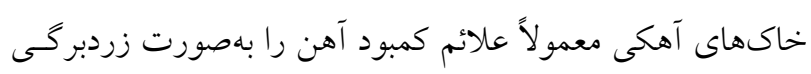

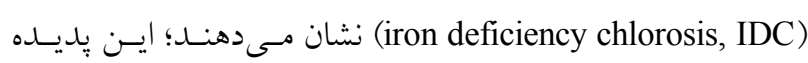

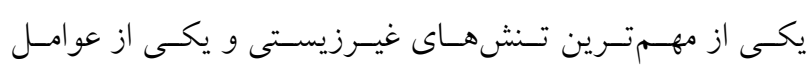

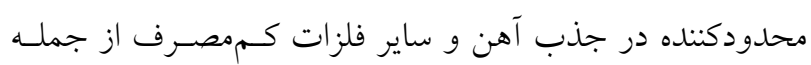

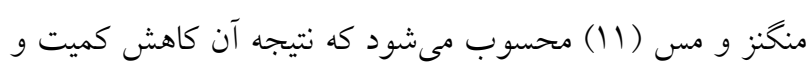

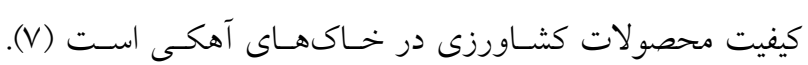

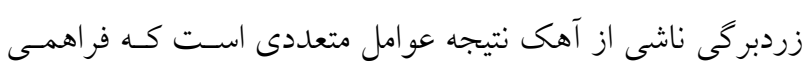

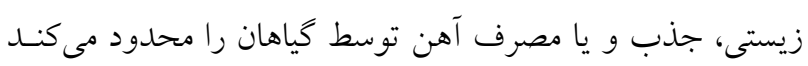

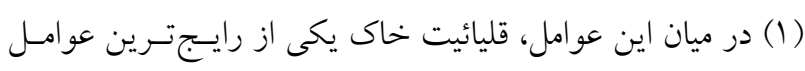

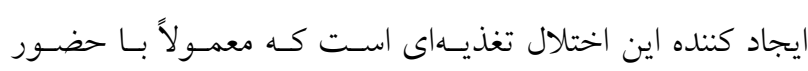

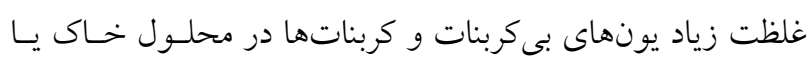

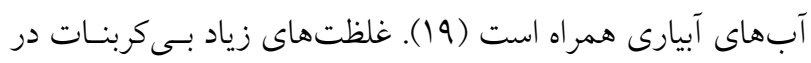

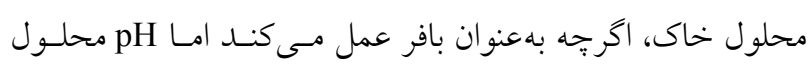

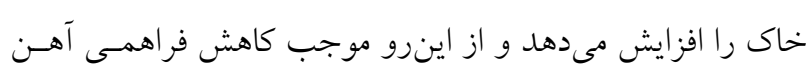

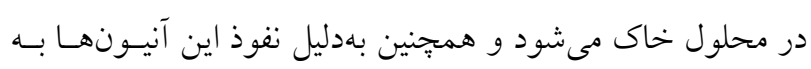

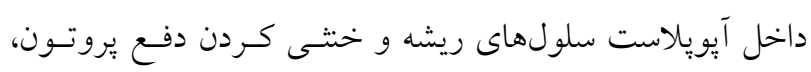

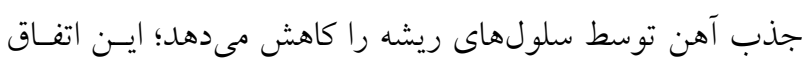

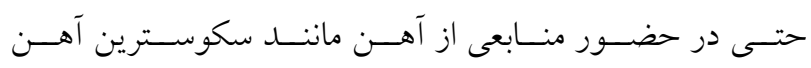
كه در رنـج وسيعى از (Fe (III) -EDDHA)

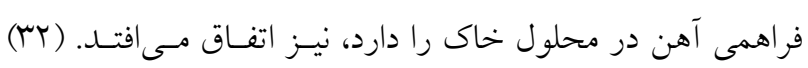

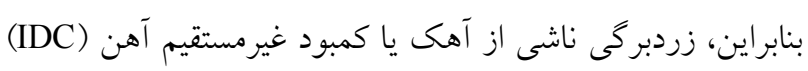

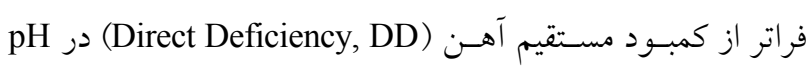

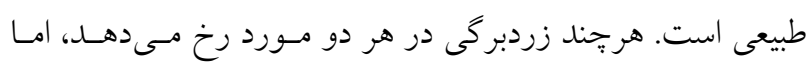


دانشكده كشاورزى دانشكاه فردوسى مشـهـد بـهـ اجـرا درآمـــ.

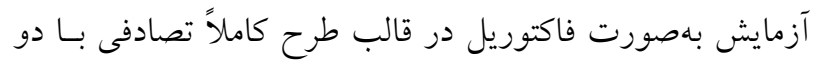

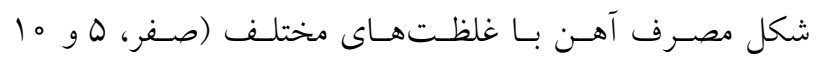

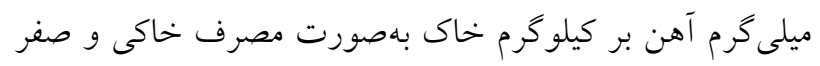

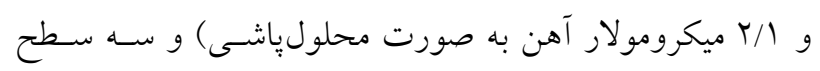
آهى (صفر، جهار و هشـت درصــ) در سـه تكـرار روى كيـاه

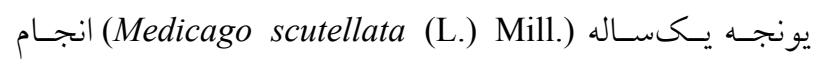
خرفت. در اين آزمايش غلظت صفر ميلى خرم آهن بـر كيلـوخرم

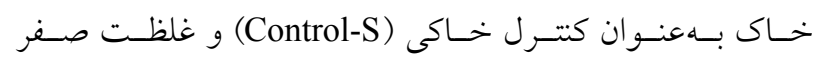

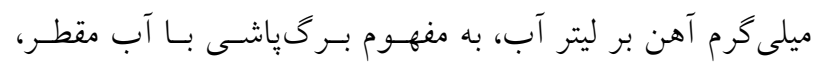

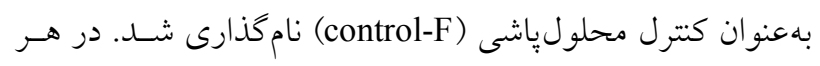

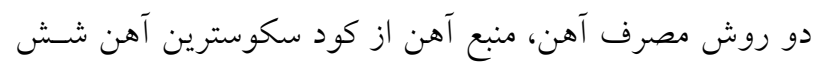

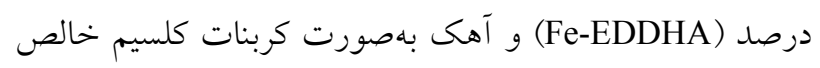
تأمين شد. انتخاب غلظتهاى آهن بر اساس عرف منطقه بـ بـراى

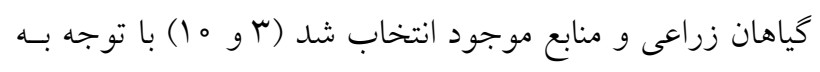

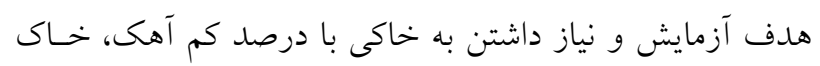

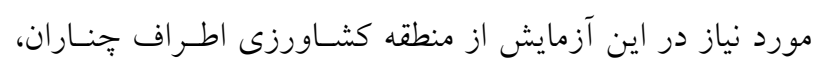

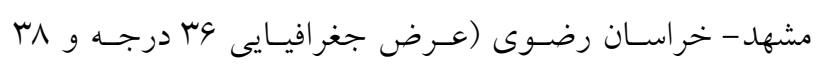

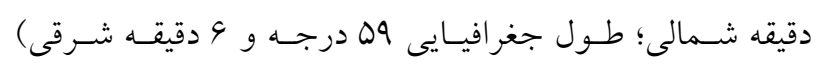

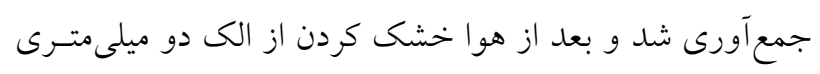

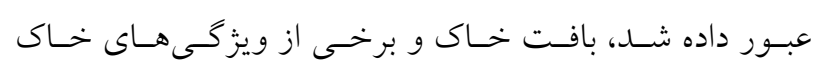

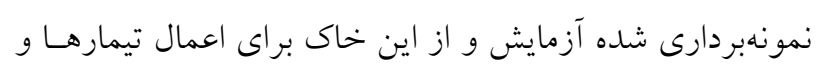

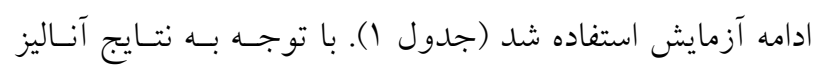

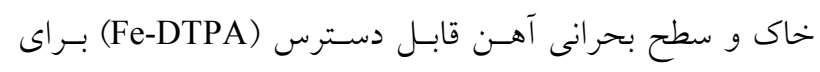

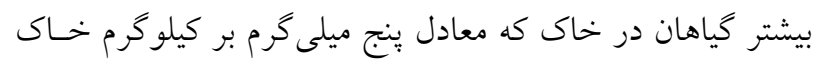

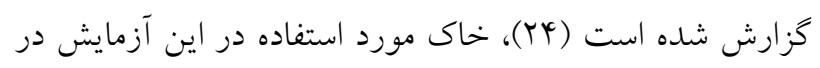

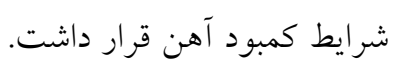

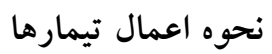

بهمنظور به تعادل رسيدن خاك اوليه با آهك، خاك بهمدت دو دو ماه

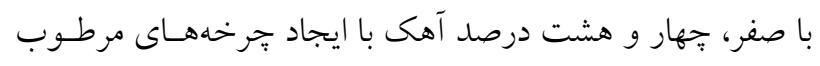

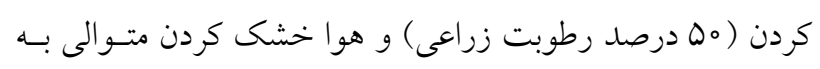

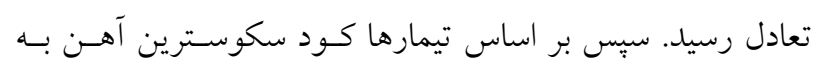

زردبركى در اين گياه در شرايط رشد مزرعه (طبيعى) مشـاهده

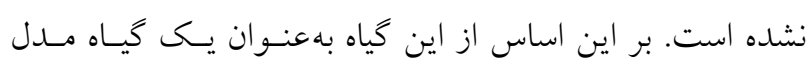

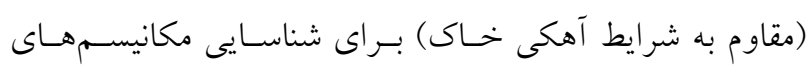

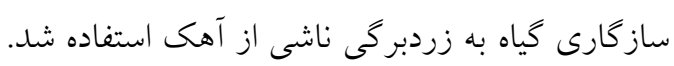

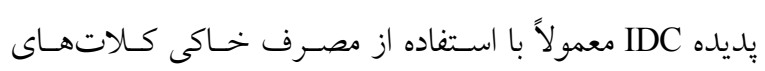
مصنوعى آهن فريك كتترل مىشود، اما اين دسته از كودها بـهـهـور

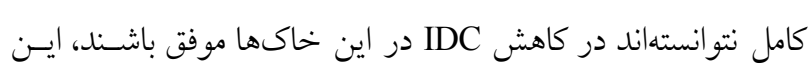

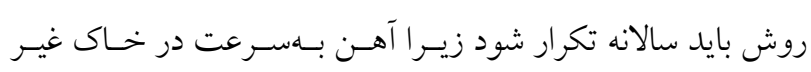

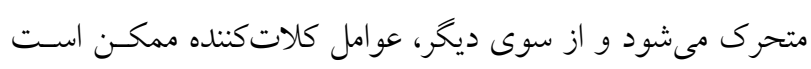

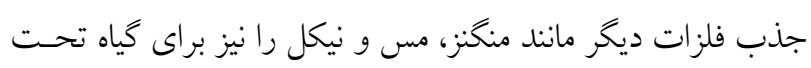

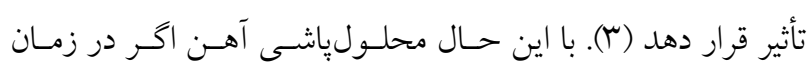

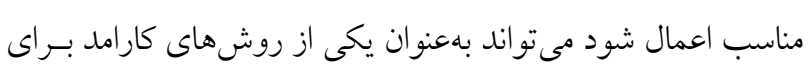

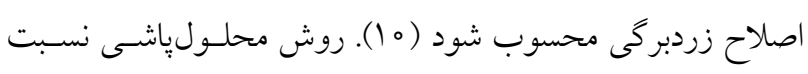

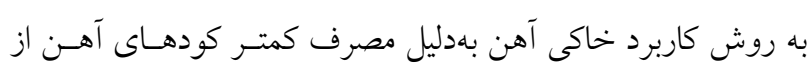

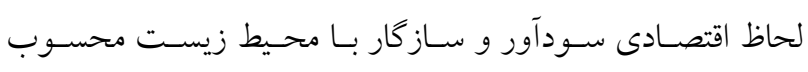

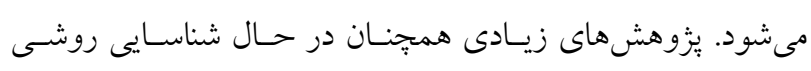

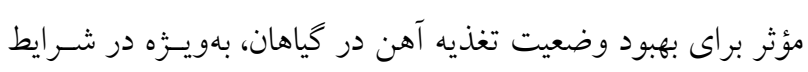

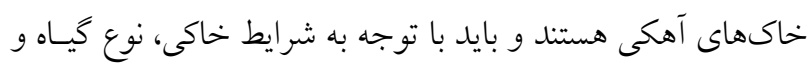

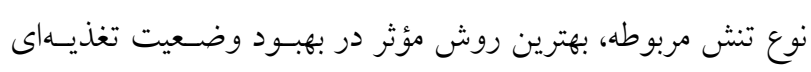

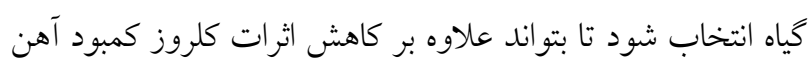
با كاهش مصرف كودها باعث حفاظت از محسيط زيست شـود. از

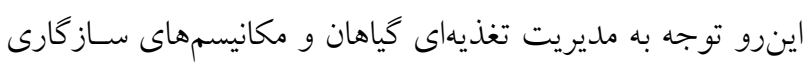

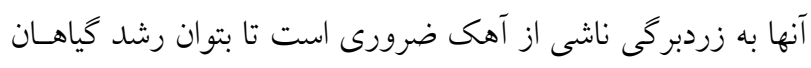

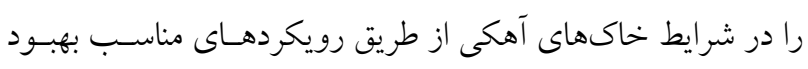

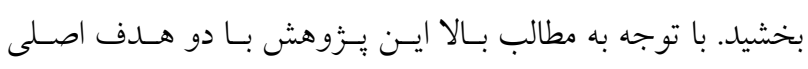

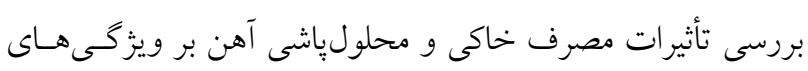

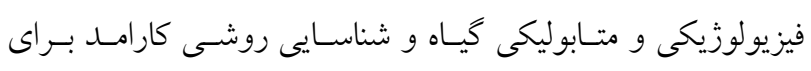
اصلاح زردبركى در شرايط خاكهاى آهكى انجام شد.

مواد و روشها تيمارهاى آزمايش و نمونهبردارى خاك اين آزمايش بلهورت كشت كلدانى در سـال وهبا در كلخانـه 
جدول ا. برخى از ويزّى هاى خاى نمونهبردارى شده در آزمايش (فسفر و يتاسيم قابل استفاده براى گياه)

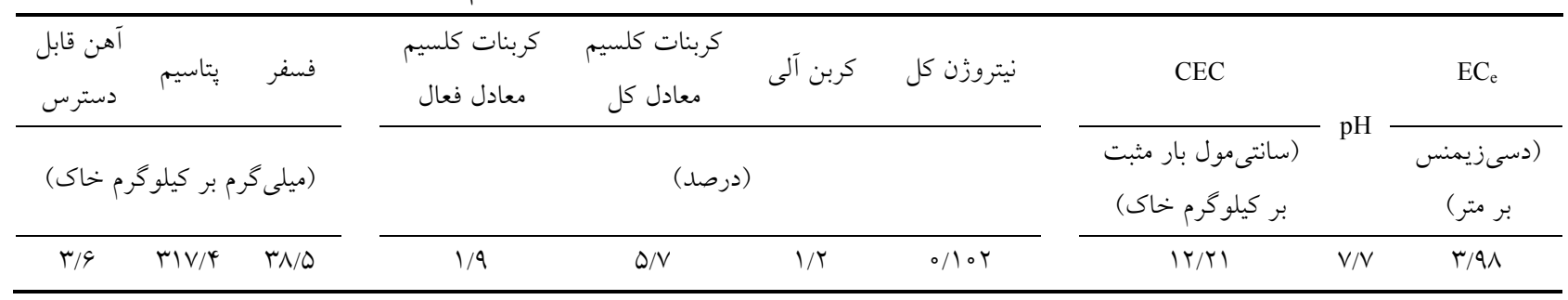

(Spectro, Arcos, Germany) مد برحب ميلى

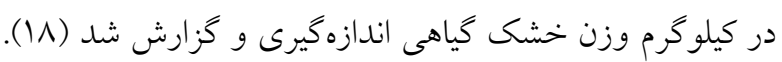

محتواى نسبى آب برى و شاخص بايدارى غشا (RWC, MSI)

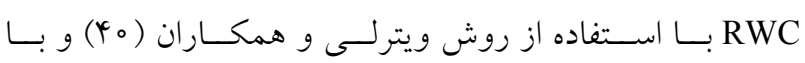

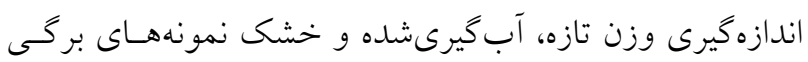

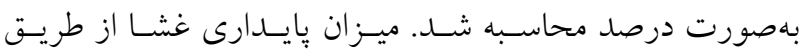

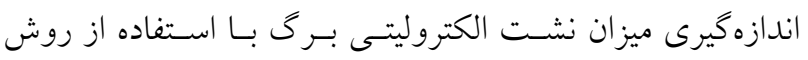
ديشموخت (r) ( ارزيابى شد.

\section{كلروفيل كل}

بهمنظور عصارهكيرى و تعيين كلروفيل كل، بافت تـازه بـرى بـاــا

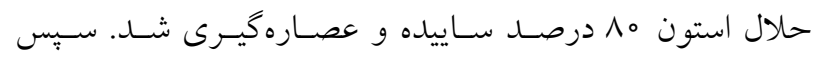

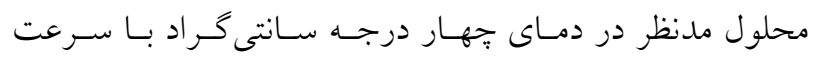

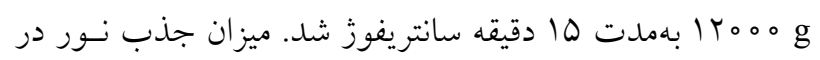

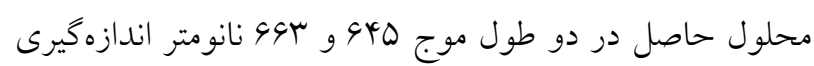

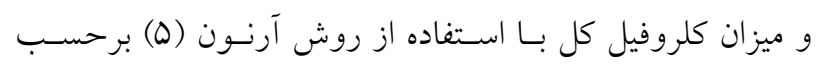

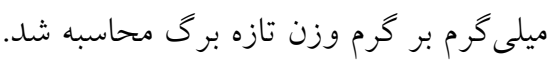

سنجش غلظت بروتئين به روش برادفورد

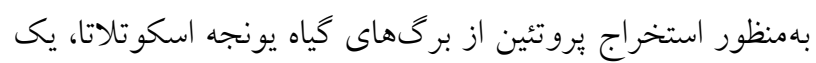

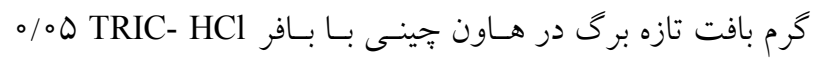

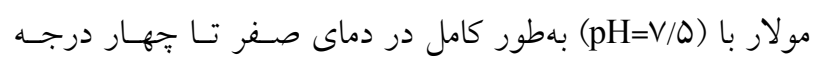

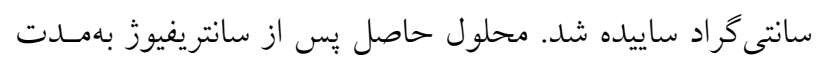

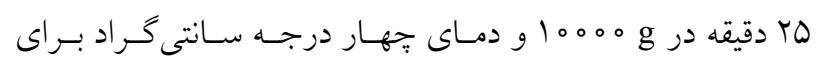

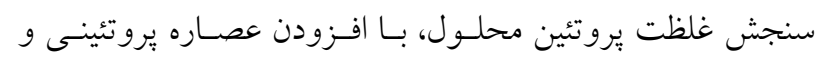

خاى اضافه شد و در مورد تيمـار محلـول ياشسى، بــدون اضـافه

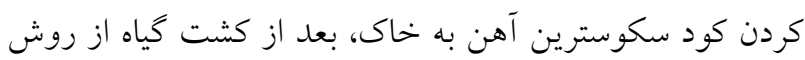

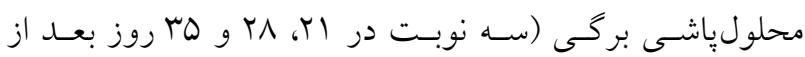
كشت كياه، هر بار بهميزان ه ما مايلى ليتر ) استفاده شد.

\section{كاشت بذر و نغهدارى گياهان}

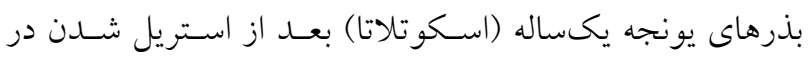

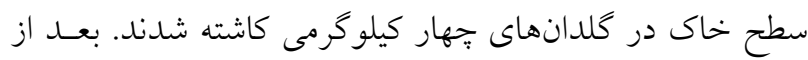

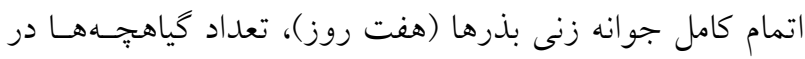

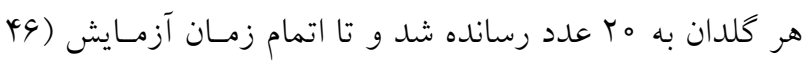

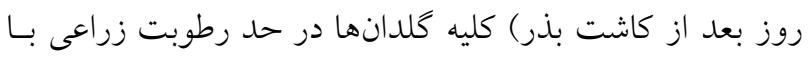

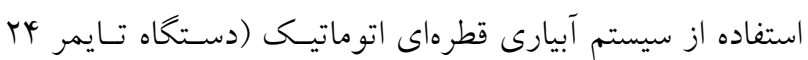

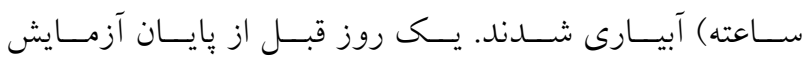

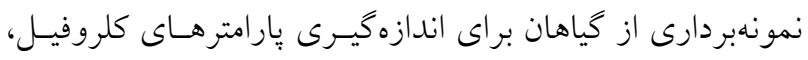

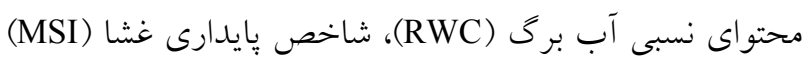

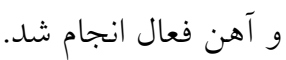

\section{برداشت گياه و اندازهيرى غلظت آهن}

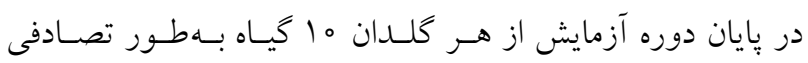

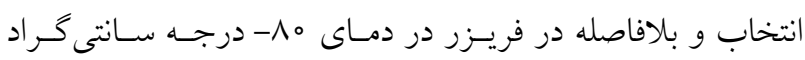

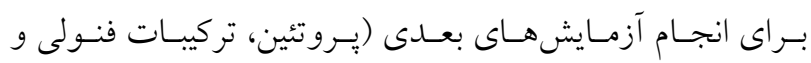

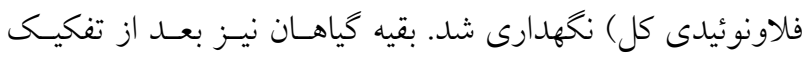

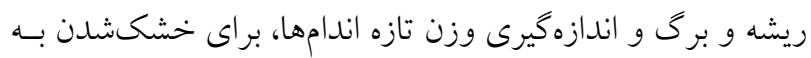

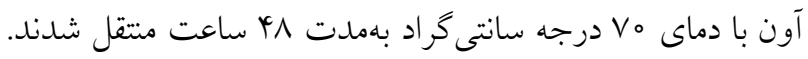

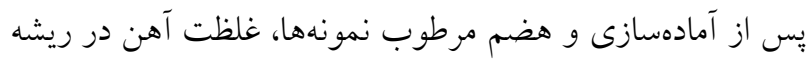

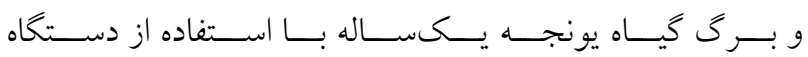


نانومتر اندازهكيرى شد. نتايج بهصسورت ميلسى گرم معـادل روتسين

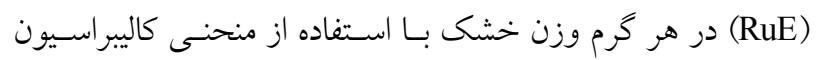
روتين (R/99V) بيان شد.

\section{تجزيهوتحليل دادهها}

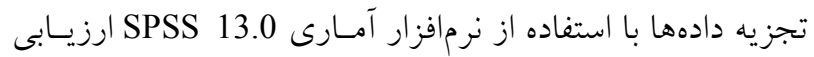

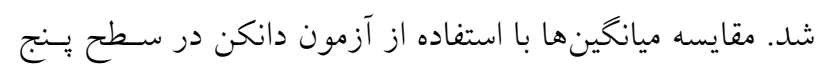

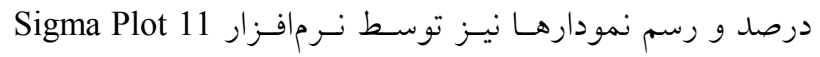

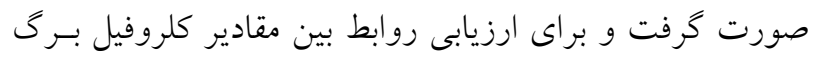

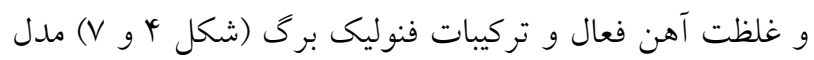
Least-squares fit linear models با معنسى دارى همبستيكى در فرد

سطح 101 استفاده شد.

\section{نتايج و بحث}

نتايج تجزيه واريانس دادها نشان داد كه برهم كنش تيمـار آهـن

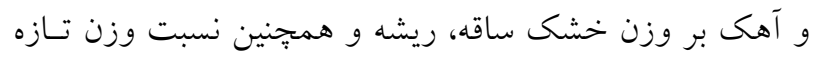

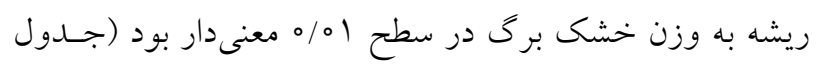

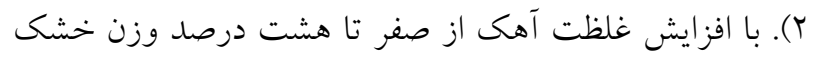

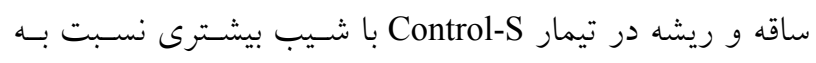

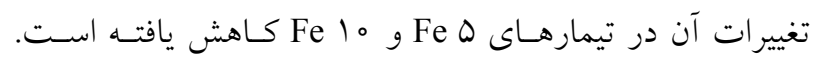

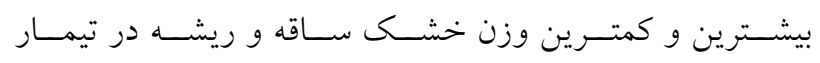

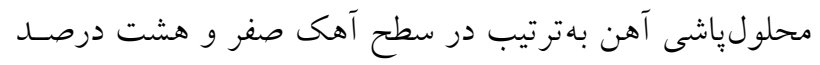

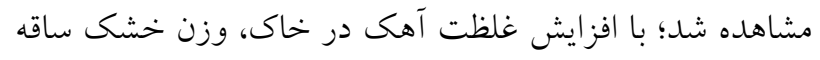

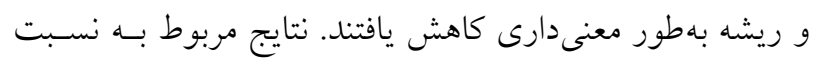

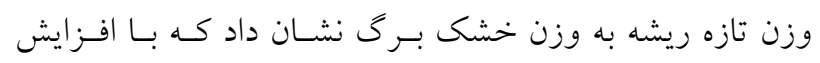
سطح آهك از صفر به جهار درصد در خاك، اين نسبت دور در كليه

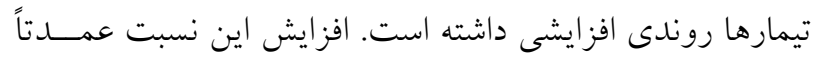

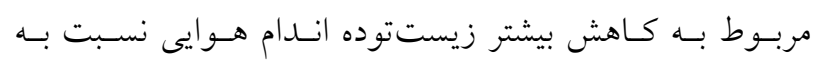

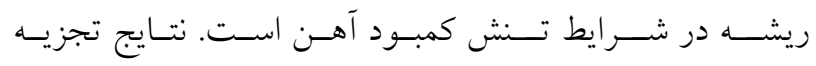

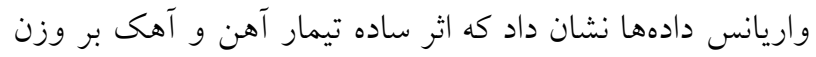

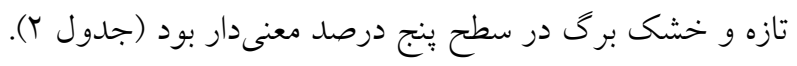

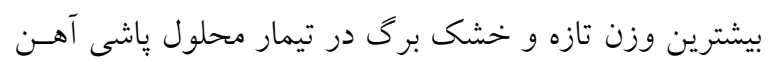

معرف بيوره استفاده و يس از دو دقيقه، جذب محلول بـا دسـتخاه

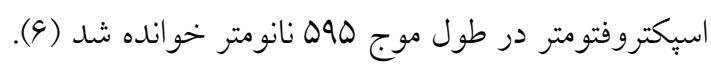

\section{آهن فعال (آهن عصاره گيرىشده با ا،ه ا فنانترولين):}

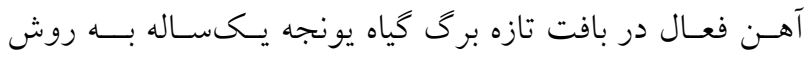

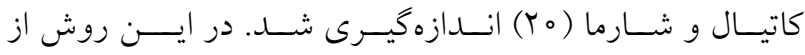
ا، ا ا فنانترولين براى استخراج آهـن بهعنوان معرف در محلـول

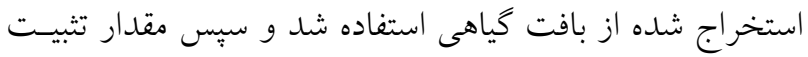

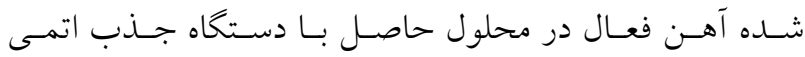
قرائت شد.

\section{اندازهيرى محتواى تركيبات فنولى و فلاونوئيدى كل} استخراج تركيبات فنولى و فلاونوئيدى بر اساس روش فئس آلـوارز يـاريلا

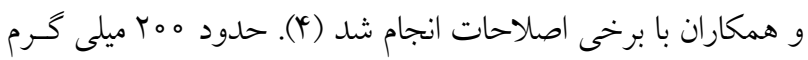

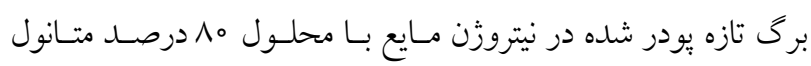

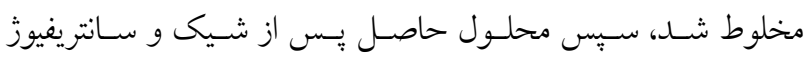

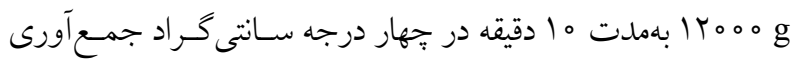

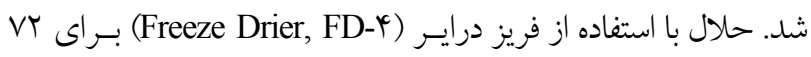

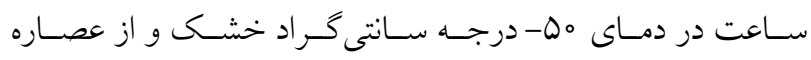

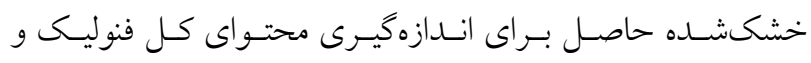

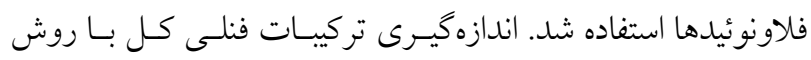

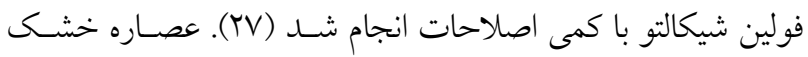

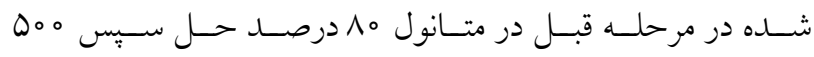

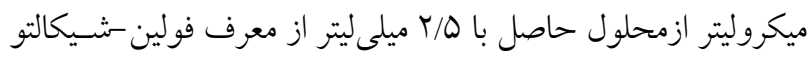

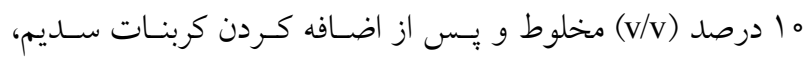

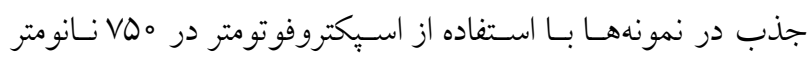

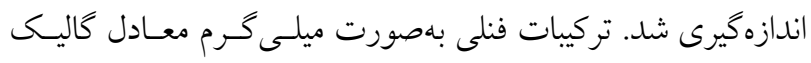

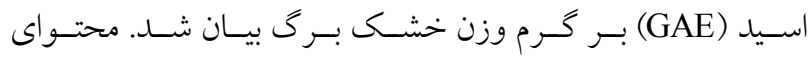

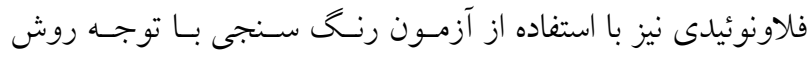

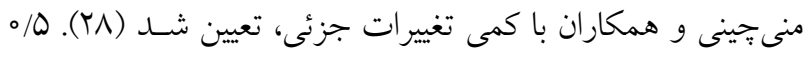

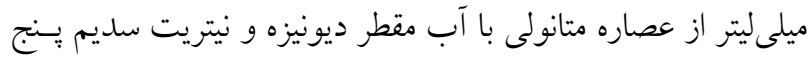

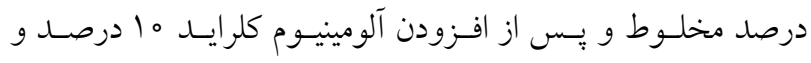

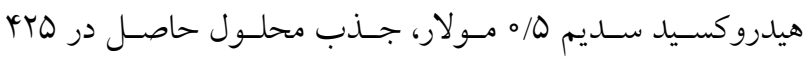


جدول r. نتايج تجزيه واريانس اثرهاى اصلى و برهم كنش فاكتورها بر وزن تازه و خشك اندامهاى گياه

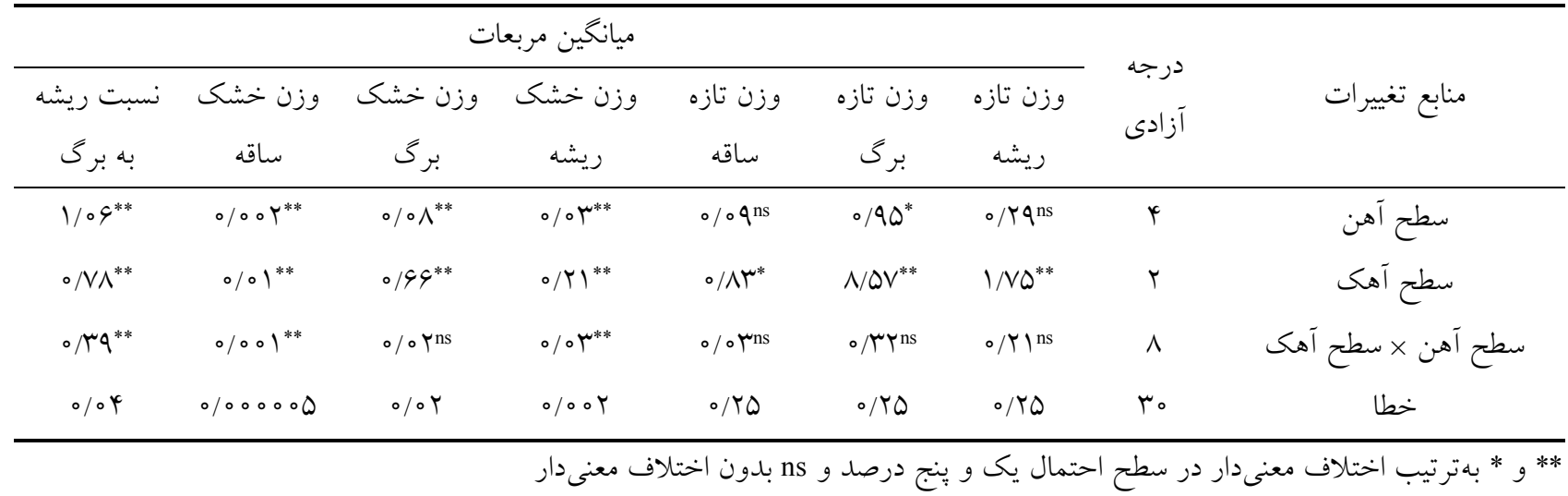

ايجاد اختلال در جذب آهن توسط كيـاه، موجـب ايجـاد عـدم تعادل در جذب سـاير عناصـر غـذايى شــده اسـت و از طرفى

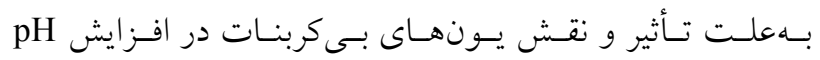

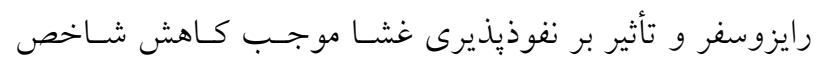

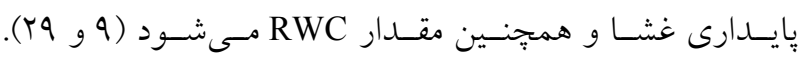
افزايش غلظت كلسيم در خاى بهواسـطه حضـور مقـادير زيـاد آهك تا حدودى مىتواند موجب كـاهش جــنب آهـن در گيـاه بهعلت وجود رابطه آنتاگونيسمى بين آنها شود، از طرفى جـذبـ زياد كلسيم توسط ريشه ممكن است موجب بـرهم زدن تعـادل

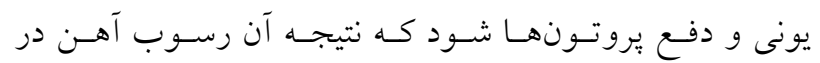

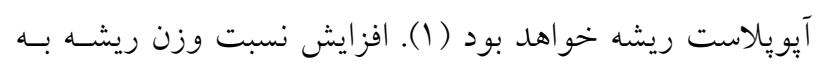
اندام هوايى در كياهان در شـرايط كمبـود آهـن بـا نتـايج سـاير يزوهشخران مطابقت داشت (19 و سو). افزايش اين نسبت يكى از مكانيسمهاى گياه در شرايط كمبود آهن محسوب مىشود كه با افزايش تعداد ريشههاى ثانويه و تمايز سـلولهـا در مريسـتم ريشه همراه است (Yq). در مقايسه با اين نتايج، گونه باى ديخـر

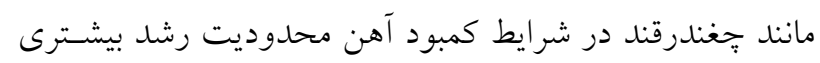

را در ريشهها نسبت به اندام هوايى نشان دادند (وس).

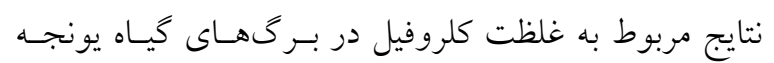
يكساله نشان داد كه هيج اثـرى از زردبركى در تيمـار كمبـود مستقيم آهن (Control-S Lime) مشاهده نشد در حسالى مـه در تيمـار كمبـود غيـر مسـتقيم آهـن (Control-S Lime) علائسم

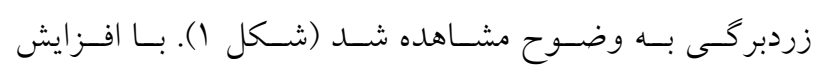

(Fe-Foliar) افزايش غلظت آهك از صفر تا هشت درصد در تيمارهـاى ه ه

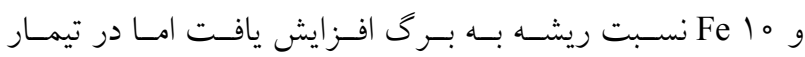

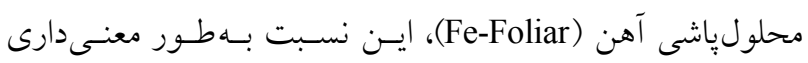

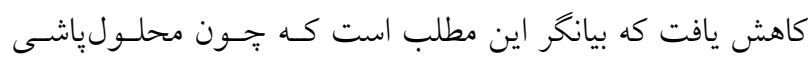
آهن نسبت به تيمار كنترل موجب افزايش معنسى اردى در وزن تـر و خشك برى شده است به همين دليل در اين تيمـار بـا افـزايش

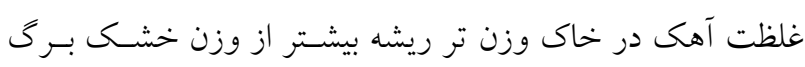
كاهش يافته است. مقايسه ميانخينهاى اثر ساده سطوح آهـى بـر

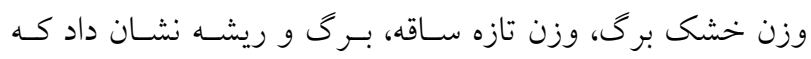
افزايش غلظت آهك تا هشت درصد موجـب كـاهش معنسى دارى در وزن اندامهاى گياهى شـده اسـت و وزن بـرگ بيشـتر از وزن ساير اندامها تحت تأثير غلظت زياد آهـك در خــاك قــرار كرفتـهـ نتايج تجزيه واريانس دادهها نشان داد كه بــرهمكـش تيمـار آهن و آهك بر RWC و MSI در سـطح يـى درصسد معنسىدار بوده است (جـــول r).افـزايش غلظـت آهـك موجـب كـاهش شديدى در RWC و MSI شد كه يكـى از دلايـل آن مسىتوانــ آند مربوط به تأثير غلظتهاى زياد آهك در خاى روى افزايش اثـر تنش اسمزى و همجنين يونى در كياه باشد ( آY). به عبـارتى بـا افزايش غلظت آهك در خاك فراهمى و قابليت اسـتفاده آب در

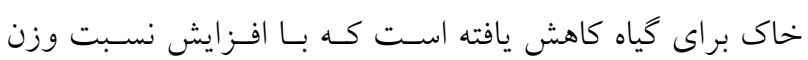
ريشه به برى همراه بود. افزايش غلظت آهك از يك طـرف بـا بـا 
مقايسه روش محلول ياشى و مصرف خاكى آهن بر ويزگگى...

جدول r. نتايج تجزيه واريانس اثرهاى اصلى و برهمكنش تيمارها بر بارامترهاى فيزيولوزيكى و غلظت و جذب آهن در گياه يونجه يكساله

\begin{tabular}{ccccccccc}
\hline \multicolumn{7}{c}{ من } & & \\
\hline \\
\end{tabular}

** و * بهترتيب اختلاف معنىدار در سطح احتمال يكى و ينج درصد و ns بدون اختلاف معنىدار

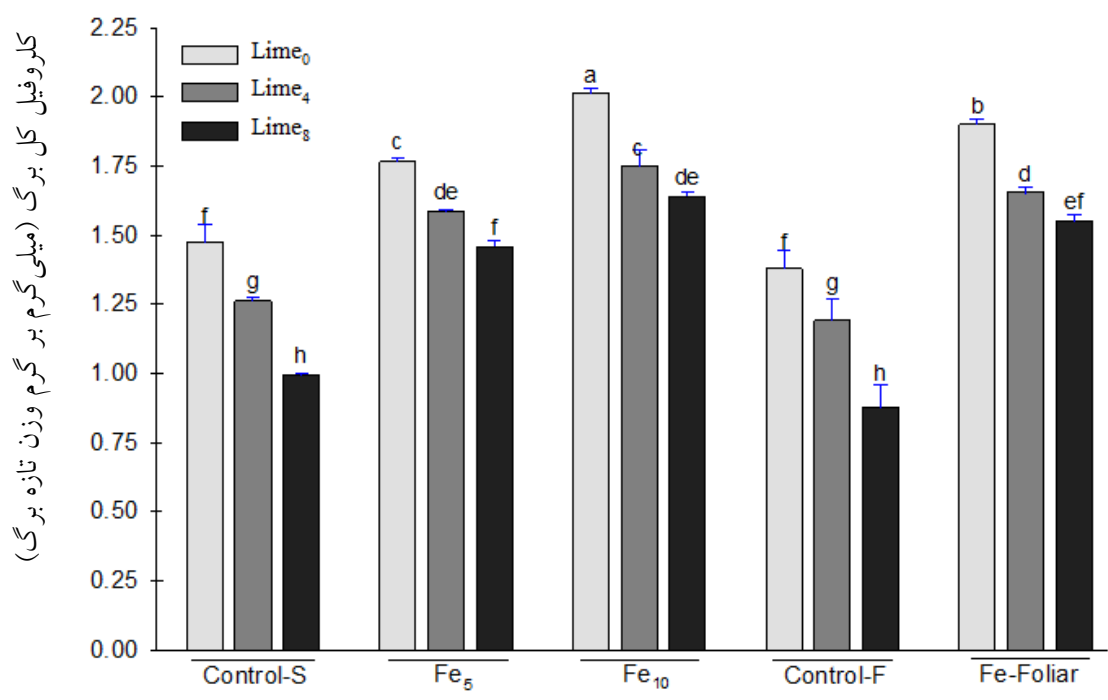

شكل ا. برهم كنش مصرف آهن (خاكى و محلولياشى) و سطوح آهك بر غلظت كلروفيل برى. حروف مشترك در ستونها، طبق آزمون

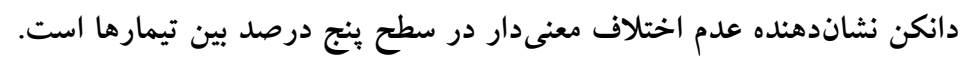

همكاران مبنى برتأثير محلول ياشى كلات آهن (III) بــر افـزايش

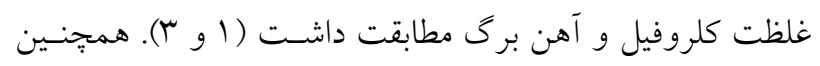

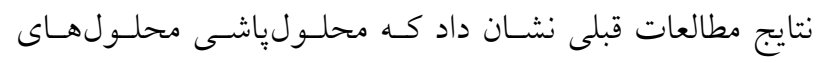

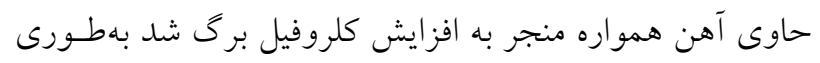

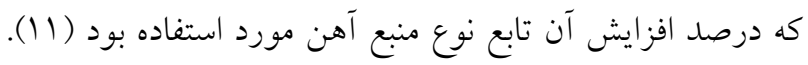

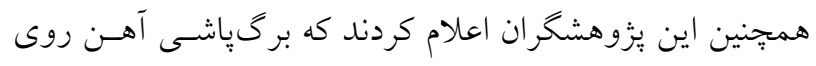

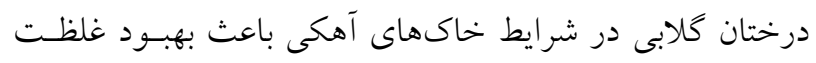

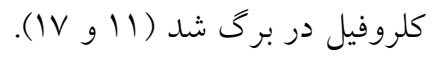

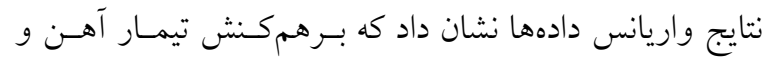

غلظـت آهـك، مفــار كلروفيـل در بـرى كياهـان بـهــــور

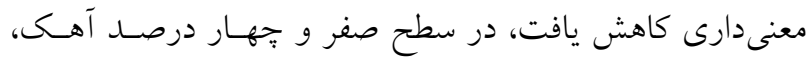

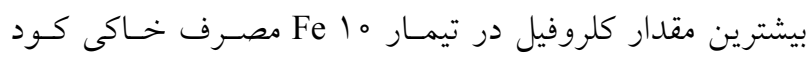

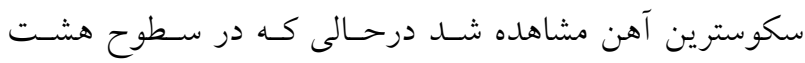

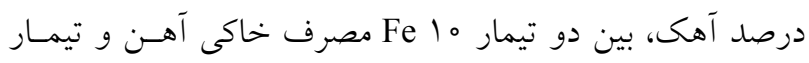

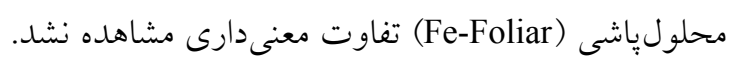

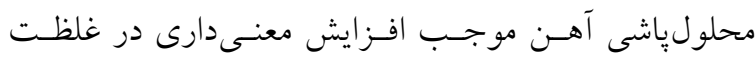

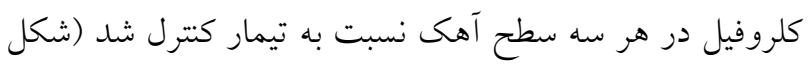

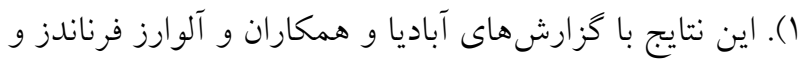


آهك از جهار به هشت درصد بهطور معنىدارى كـاهش يافـت

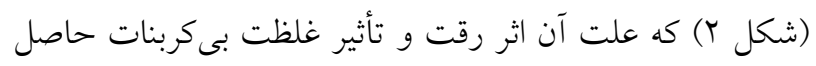

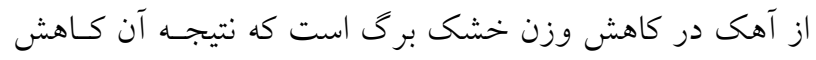

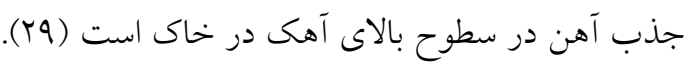

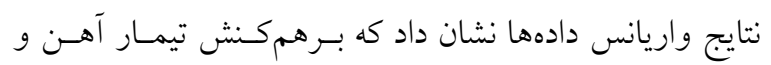

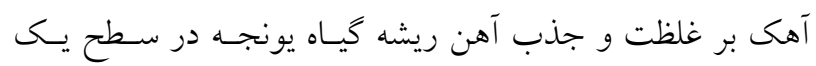

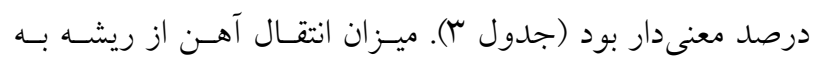

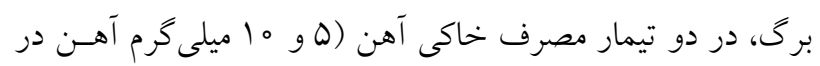

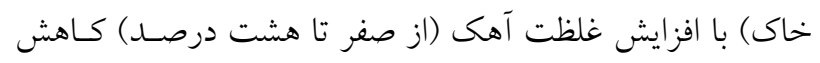

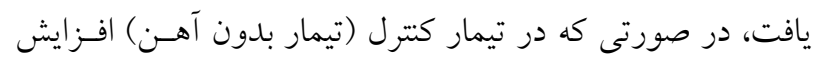

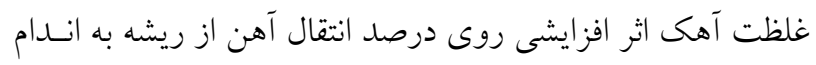

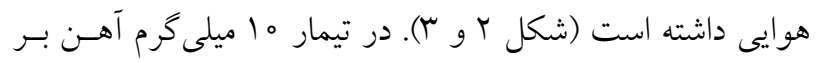

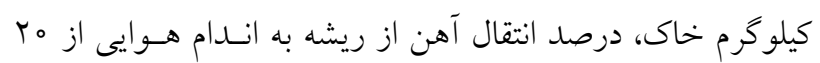

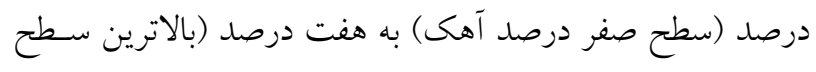
آهك) كاهش يافت. مطالعات انجامشده روى كياه يونجه يكساله درصد

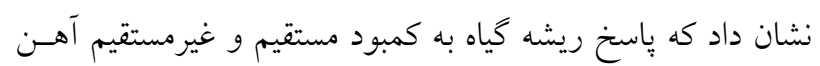

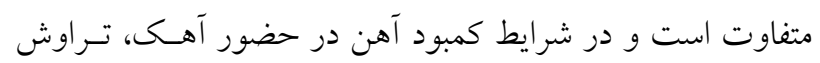

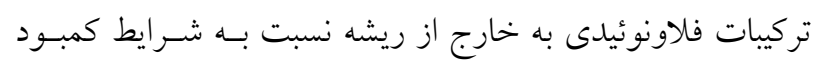

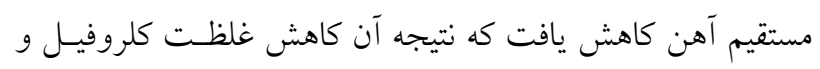

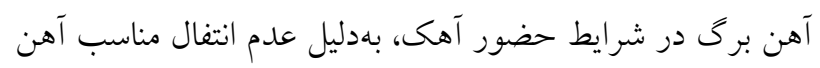

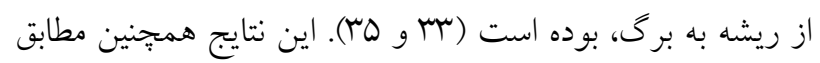

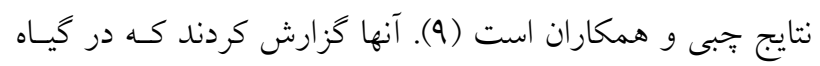

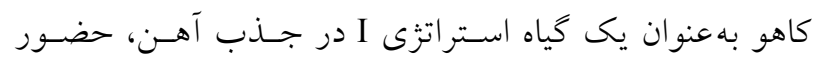

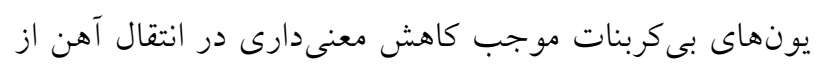

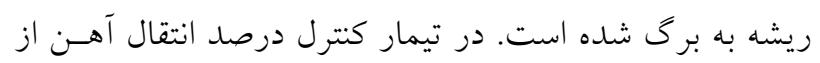

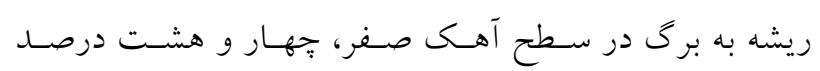

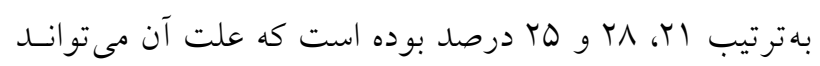

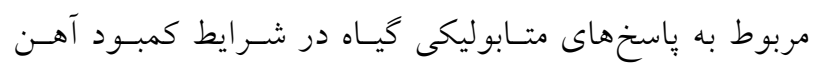

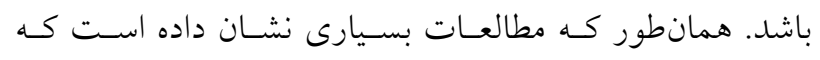

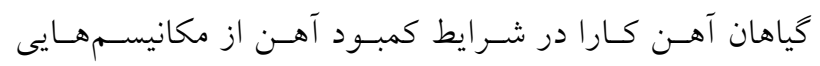

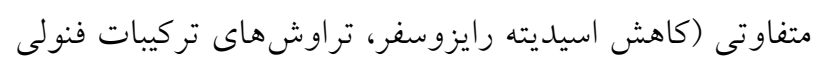

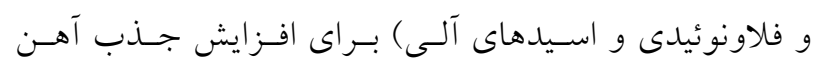

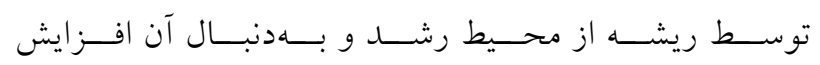

آهك بر غلظت آهن كل و فعال (Fe

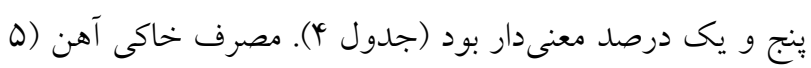

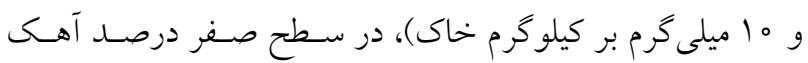

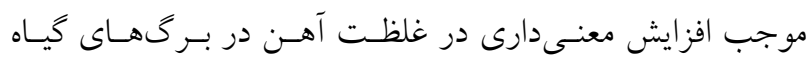

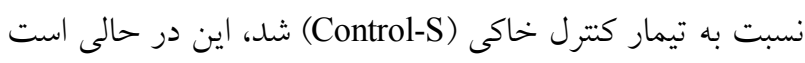

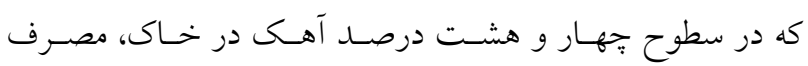

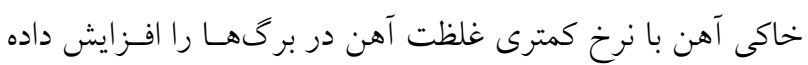

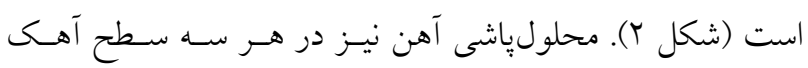

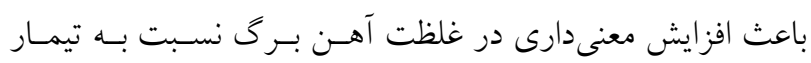

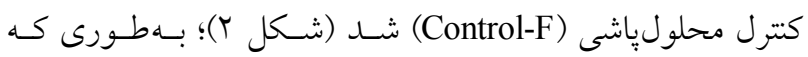
بيشترين غلظت آهن در برى و در هر سه سطح آهـى در تيمـار

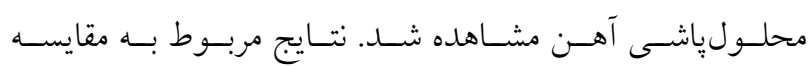

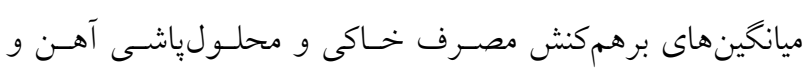

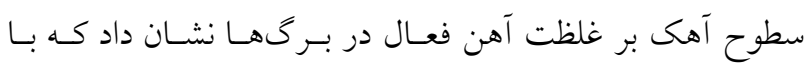

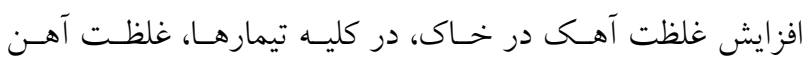
دوظرفيتى در برى كياه بهطور معنى دارى كاهش يافت (شكل r T).

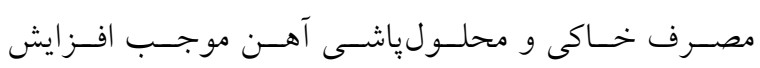

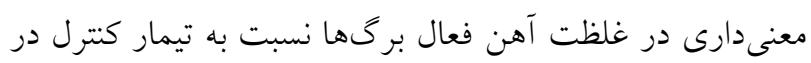

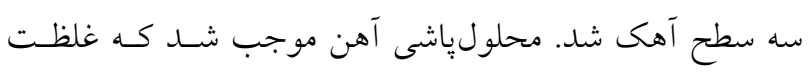

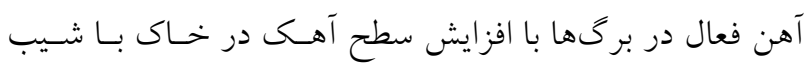

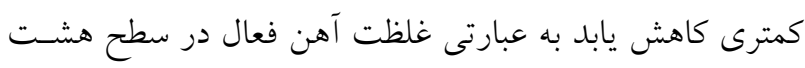
درصد آهـى در خـاك در تيمـارمحلولياشسى بيشـتر از تيمـار

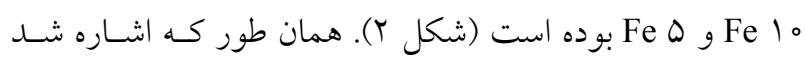

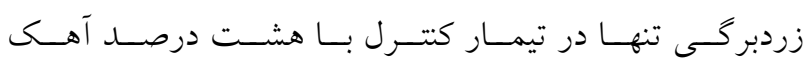
(Control-S Lime)

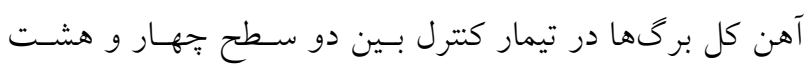

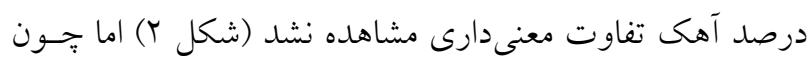

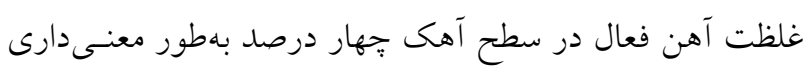
بيشتر از سطح آهك هشت درصد بود (شكل r ()، درنتيجه علائم

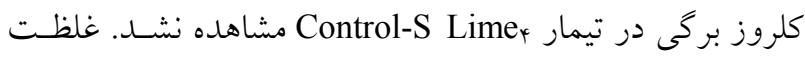

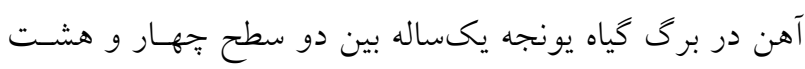

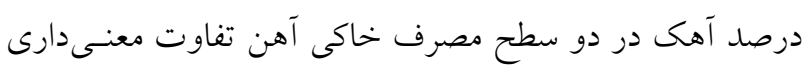

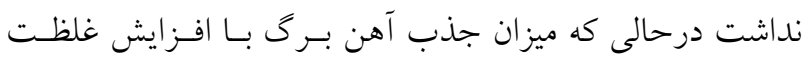


مقايسه روش محلول ياشى و مصرف خاكى آهن بر ويزگىى...

جدول ب. نتايج تجزيه واريانس اثرهاى اصلى و برهمكنش تيمارها بر برخى بارامترهاى بيوشيميايى و غلظت آهن برى در گياه يونجه يكساله

\begin{tabular}{|c|c|c|c|c|c|c|}
\hline \multicolumn{5}{|c|}{ ميانكين مربعات } & \multirow{2}{*}{ آزادى } & \multirow{2}{*}{ منابع تغييرات } \\
\hline فنل كل برى & فلاونوئيد كل برى & غلظت أهن فعال برى & غلظت آهن برى & يروتئين & & \\
\hline $49 \& / \Lambda \kappa^{* *}$ & $T V / q V^{* *}$ & GTI/Aq** & 1. YYNNII:* & $\Lambda V / 99^{* *}$ & r & سطح آهن \\
\hline$\Lambda \Upsilon 9 / \Lambda^{* * *}$ & $K Y / Y^{* * *}$ & $94 \% / N^{* * *}$ & $V \times \& 9 / 01^{* *}$ & $099 / 90^{* *}$ & r & سطح آهى \\
\hline $1 \cdot 0 / 1 q^{\mathrm{ns}}$ & $4 / 90^{* *}$ & $V / 9 V^{* *}$ & $199 / \Upsilon \Lambda^{* *}$ & $\kappa V / r V^{*}$ & $\wedge$ & سطح آهن × سطح آهى \\
\hline INT & $\% \% V$ & $\circ / V V$ & $V T / N Q$ & $1 / 09$ & r。 & خطا \\
\hline
\end{tabular}

"** " بهترتيب اختلاف معنى دار در سطح احتمال يك و ينج درصد و ns بدون اختلاف معنى دار

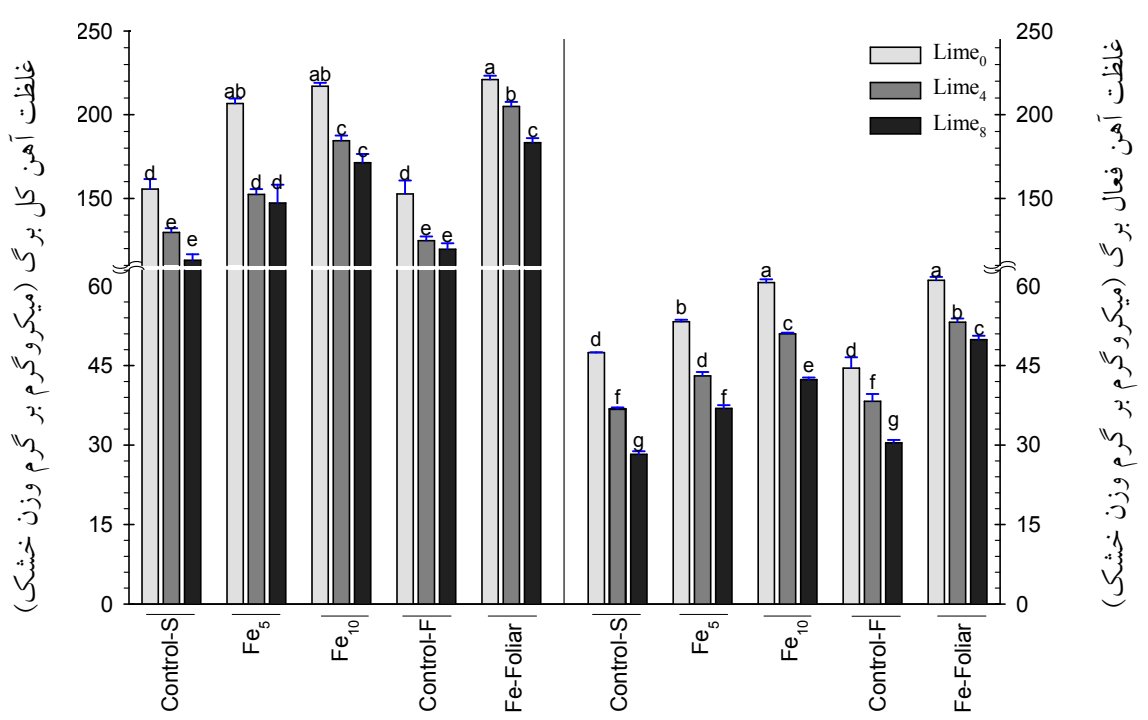

شكل r. برهم كنش مصرف آهن (خاكى و محلول ياشى) و سطوح آهك بر غلظت آهن كل و آهن فعال در برى گياه يونجه يكساله. حروف مشترك در

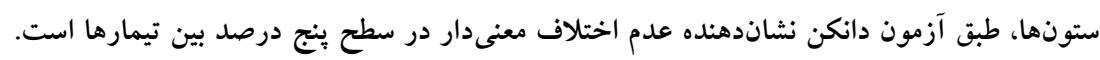

مصرف خاكى آهن مشاهده شد. نتايج حاصـل از ايـن يـزّوهش

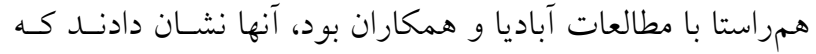
غلظت آهن در ريشه كَاهان رشد يافته (كَاهان استراتزى II) در

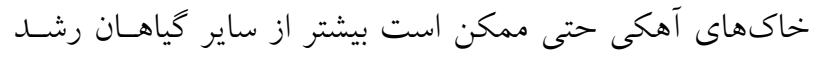

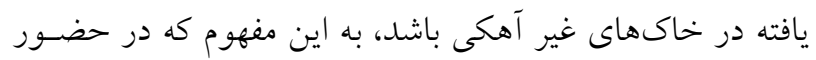

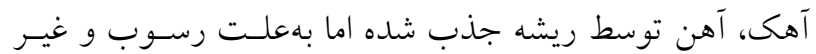

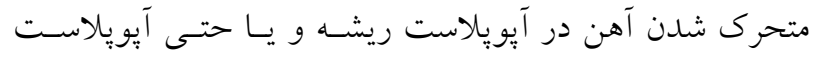

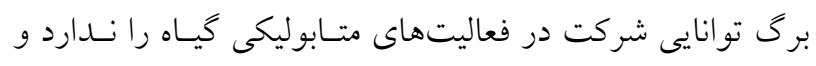

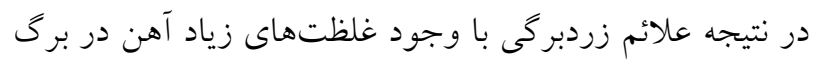

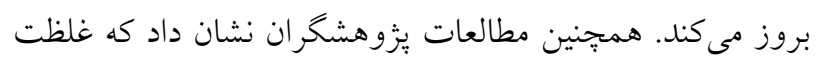

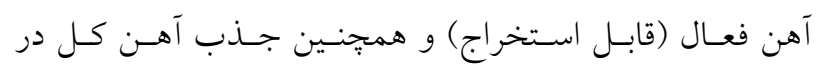

انتقال آهن جذب شده از ريشه به برك استفاده مسىكنـــ (Yl و و TD TS. در تيمار كنترل، افزايش غلظت آهك در خاك از جهار بـهـ هشت درصد، اثر معنى دارى روى غلظت آهن ريشه كَاه يونجه

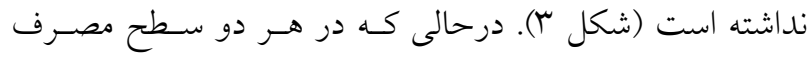

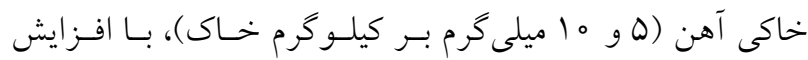
غلظت آهك تا هشت درصـد، موجـب افـزايش معنسى دارى در غلظت آهن در ريشه شد. در تيمار محلولياشى آهن نيز بين سه

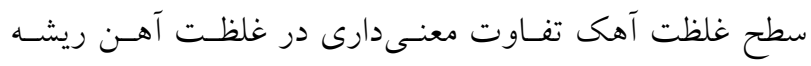

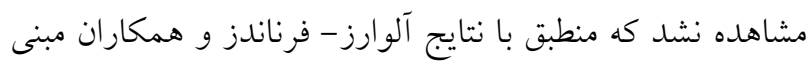

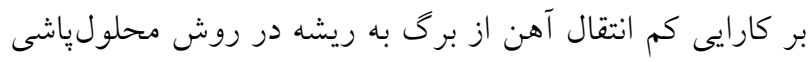

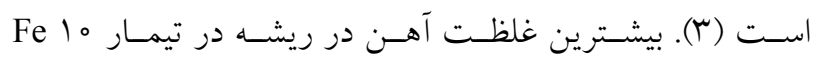




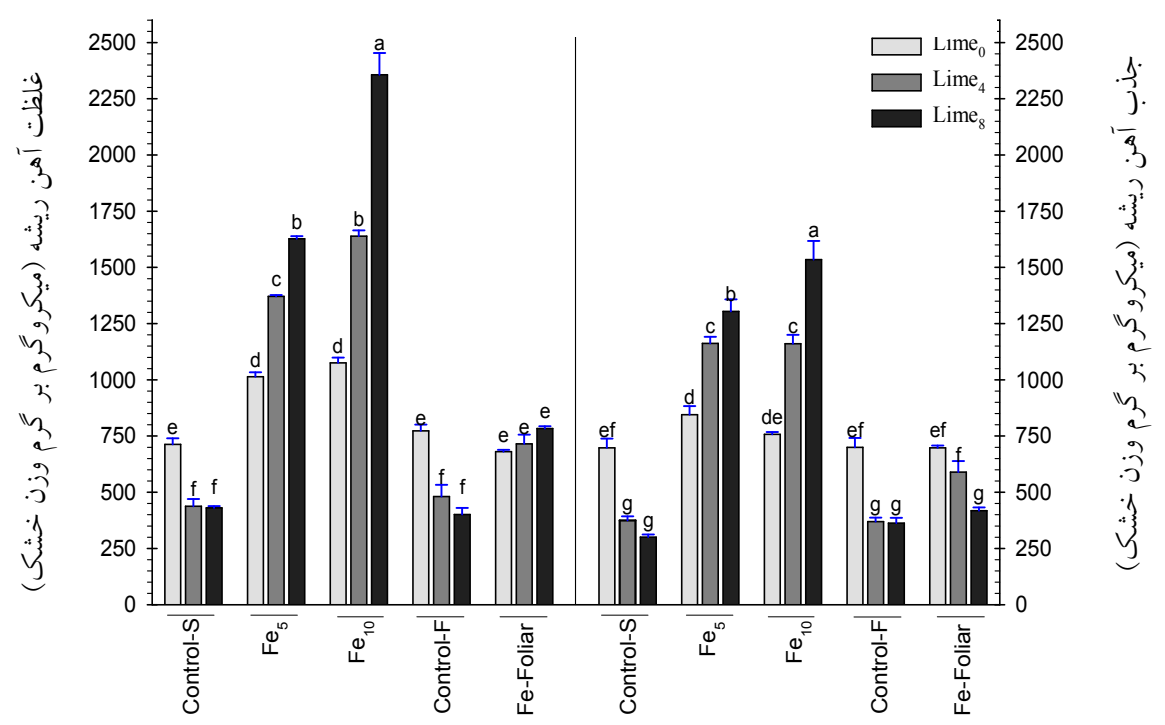

شكل r. برهم كنش مصرف آهن (خاكى و محلولياشى) و سطوح آهك بر غلظت و جذب آهن ريشه كياه يونجه يكساله. حروف مشترك در ستوذها، طبق آزمون دانكن نشاندهنده عدم اختلاف معنىدار در سطح بنج درصد بين تيمارها است.

از آهن كل كاهش يافت. همجنين جذب آهـن كـل و فعـال، بـا افزايش غلظت آهك در خاك بلطور معنىدارى كـاهش يافت. بلهورى كه اختلاف كاهش در ميزان جذب بين دو سطح صـفر

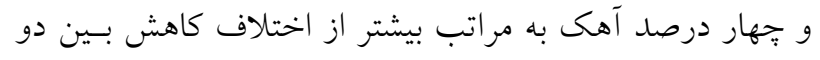

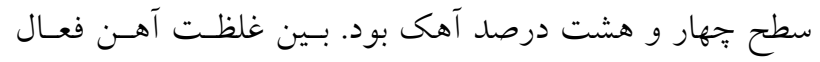
$\left(\mathrm{R}^{\Upsilon}=0 / \Lambda 9\right)\left(\mathrm{Fe}^{\Upsilon+}\right)$

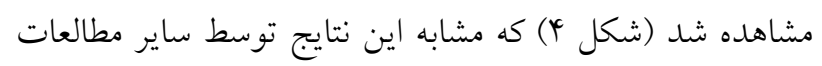

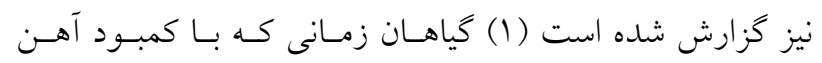
مواجه مىشوند در معـرض مشـكلات مربـوط بــه عـدم تعـادل

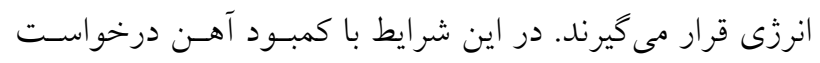

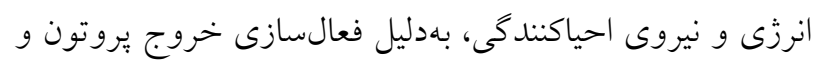

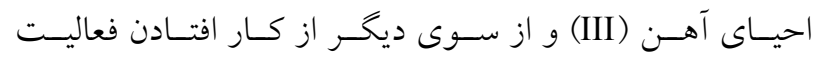

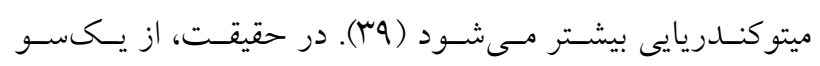

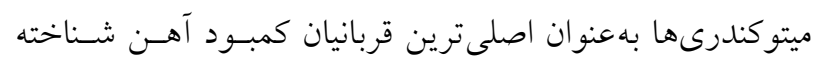

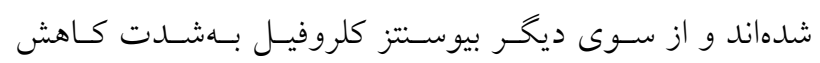

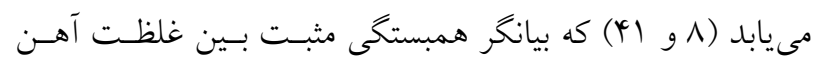

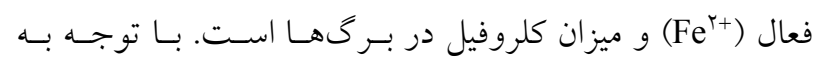
همبستخى مثبت و قوى بين غلظت آهن فعال و كلروفيـل بـرى
بركاى كياهان در شرايط IDC به مراتب كمتر از گياهان رشد

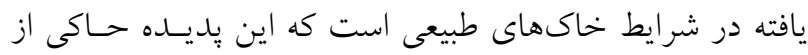

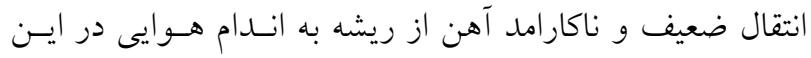

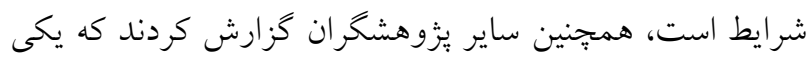

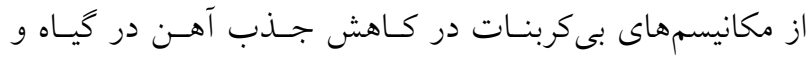
ايجاد زردبركى، مربوط به اثر اين يون در غيرمتحركسازى آهن

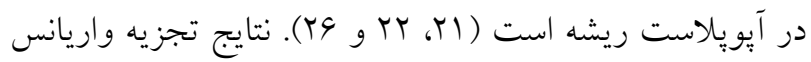

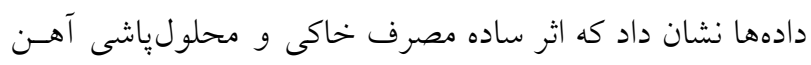

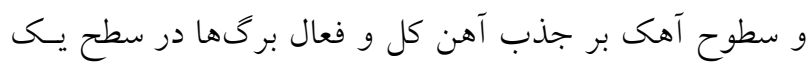

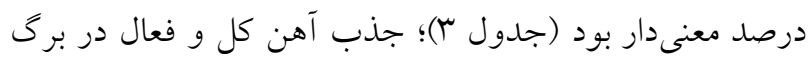

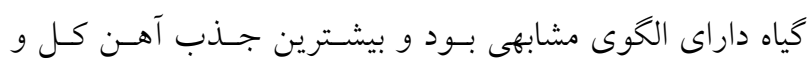

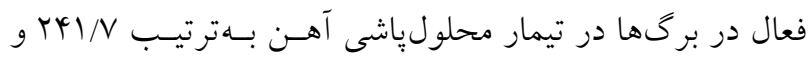

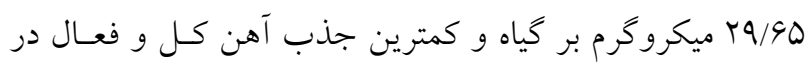

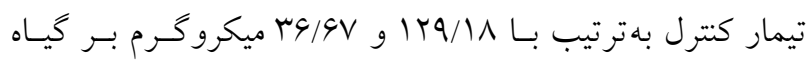

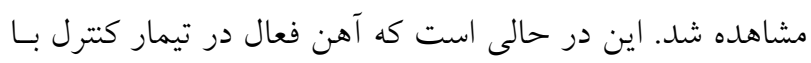

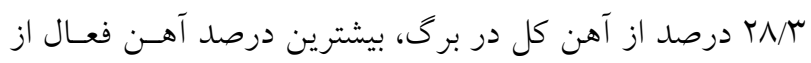

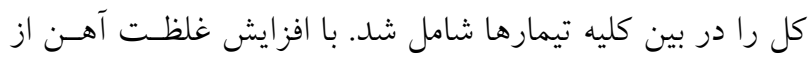
صفر به هو ه ا ميلى گرم بر كيلو گرم در خاك درصد آهن فعـال 


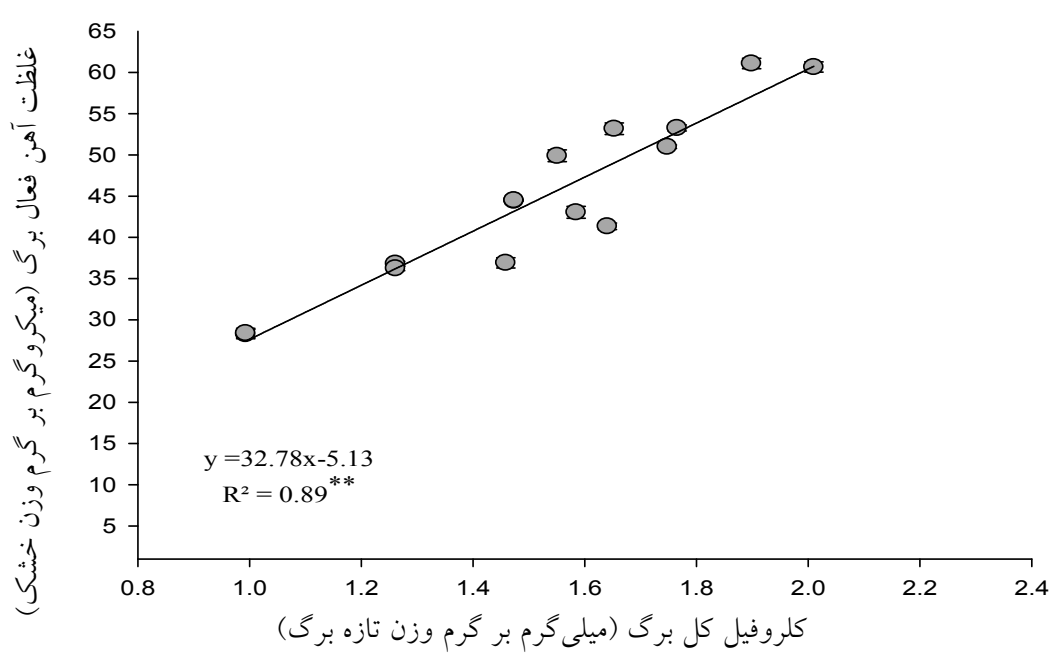

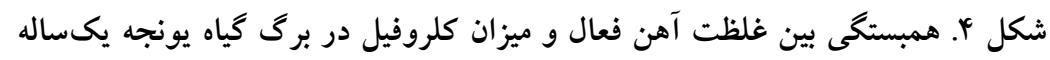

سطح آهك در خاك، تفاوت جشـمخيرى مشـاهده نشــد. در دو سطح صفر و هشت درصد آهك غلظت تبروتئين در ايسن تيمـار

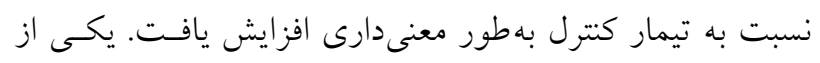

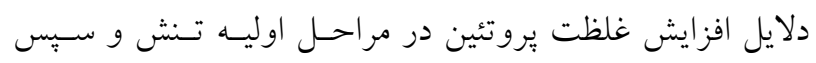

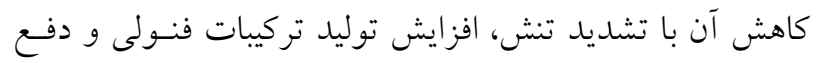

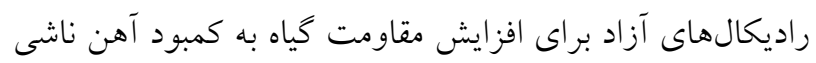

$$
\text { از حضور آهك در خاك است. (19). }
$$

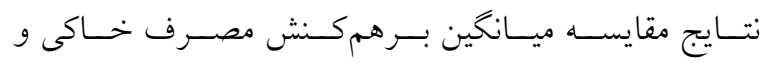

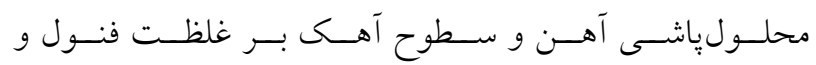

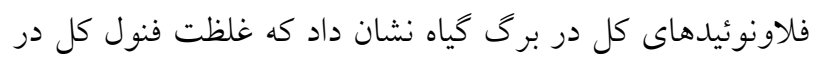

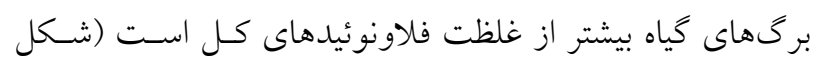

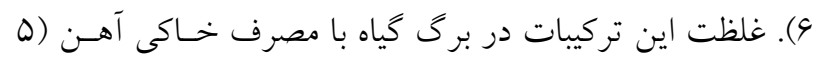

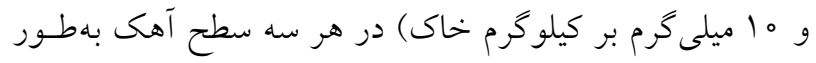

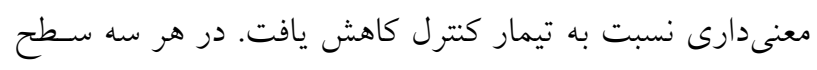

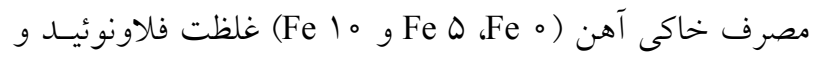

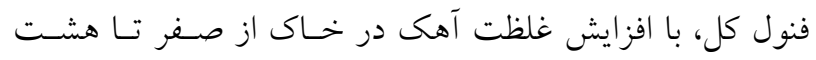

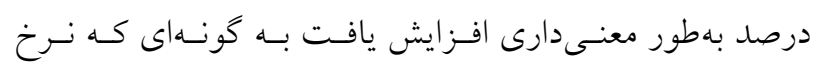

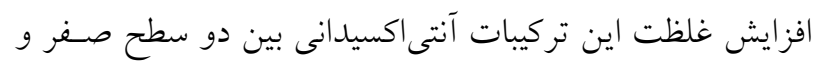

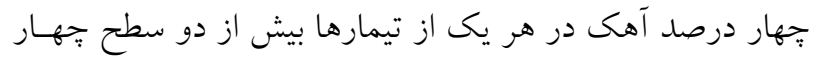

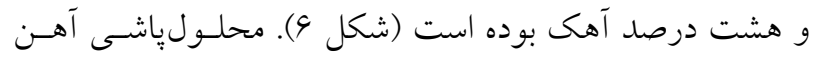
نيز بهطور معنى دارى باعث كاهش غلظت فنول و فلاونوئيد كـل
مى توان نتيجه گرفت كه غلظت آهن فعال در بركهــا مسى توانـــ

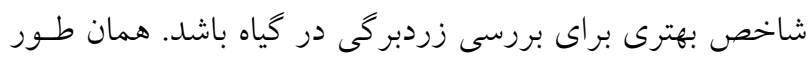

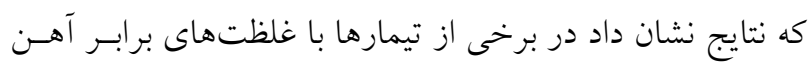

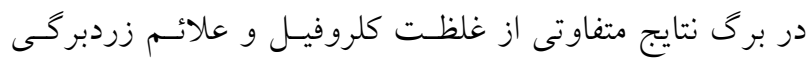

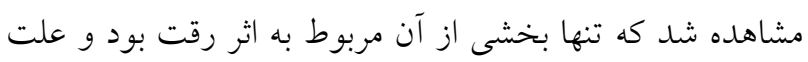

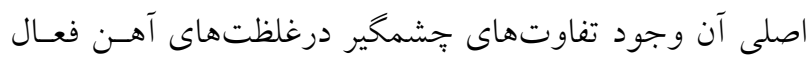

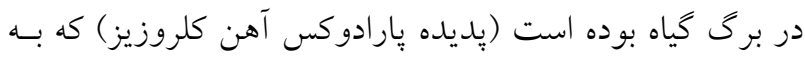

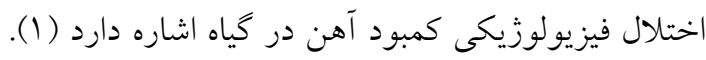

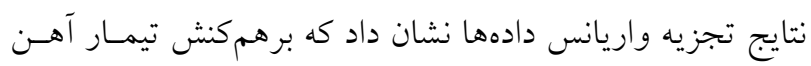

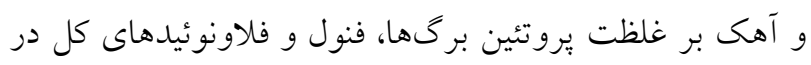

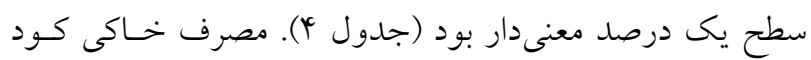

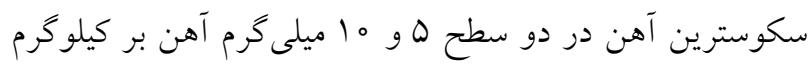
خاك، موجب افزايش معنىدارى در غلظت يروتئين بركهـا در

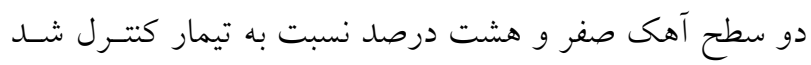

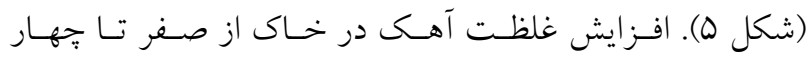

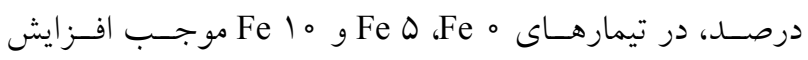

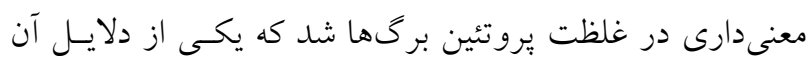

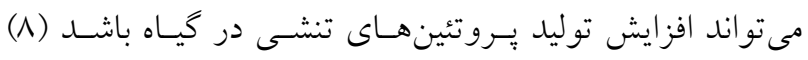

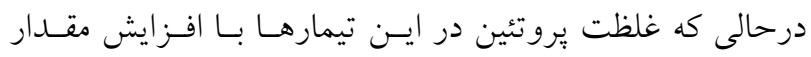

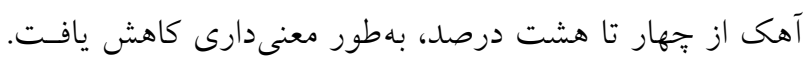

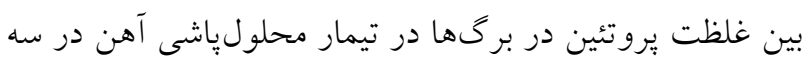




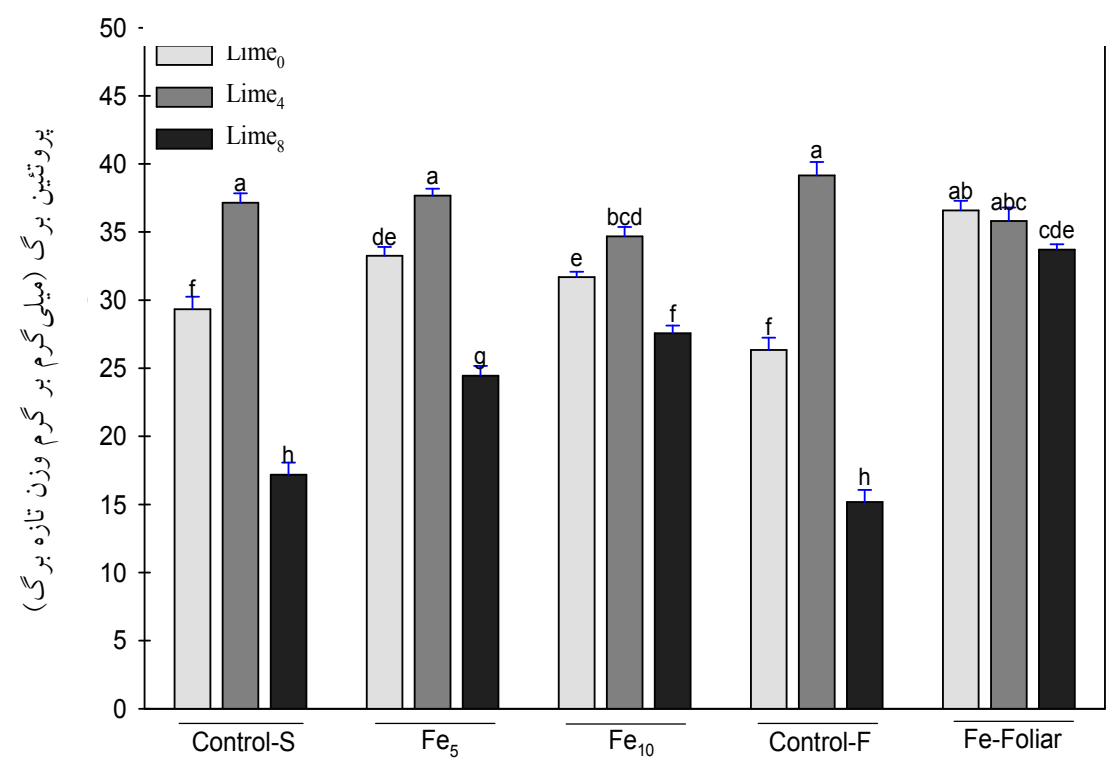

شكل ه. برهم كنش مصرف آهن (خاكى و محلول ياشى) و سطوح آهك بر غلظت بروتئين در برك يونجه يكساله. حروف مشترك در ستوذها، طبق

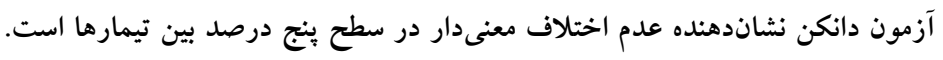

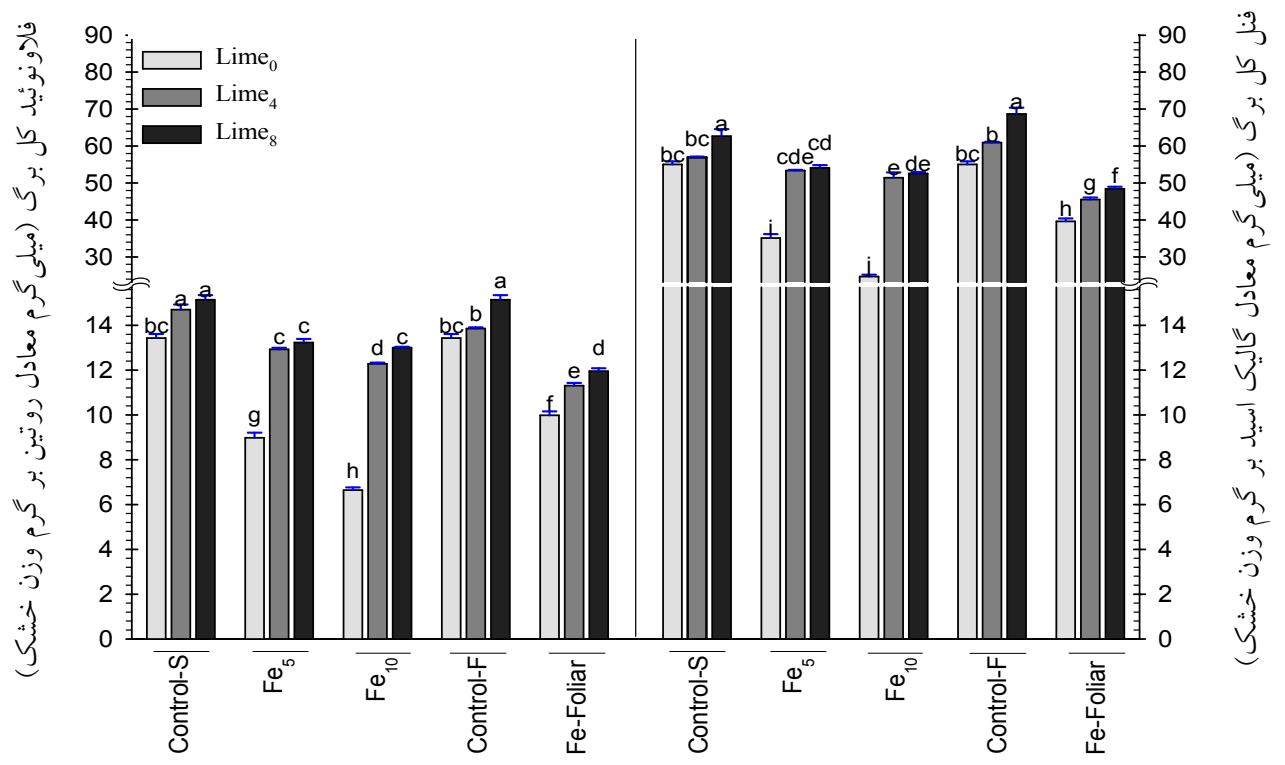

شكل 9. برهم كنش مصرف آهن (خاكى و محلولياشى) و سطوح آهك بر غلظت فنول و فلاونوئيدهاى كل در برى كياه. حروف مشترى در ستونها،

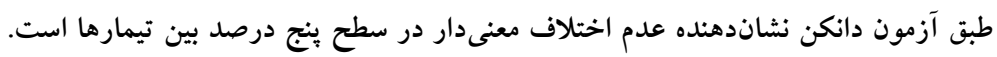

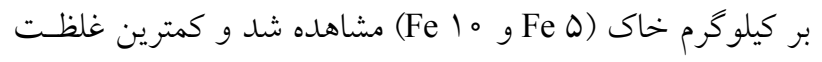

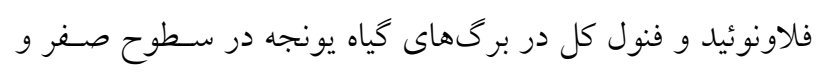

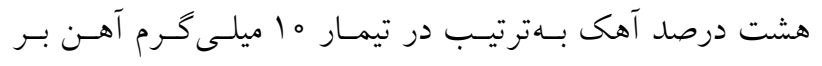

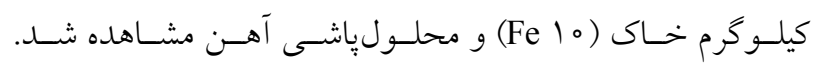

در هر سه سطح آهك نسبت به تيمار كنترل شد. در بين دو سطح

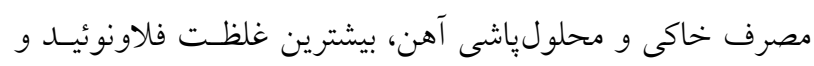

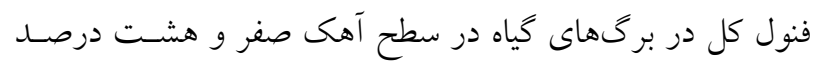

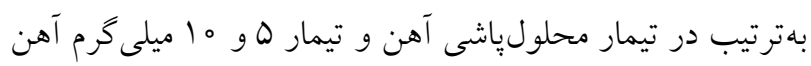



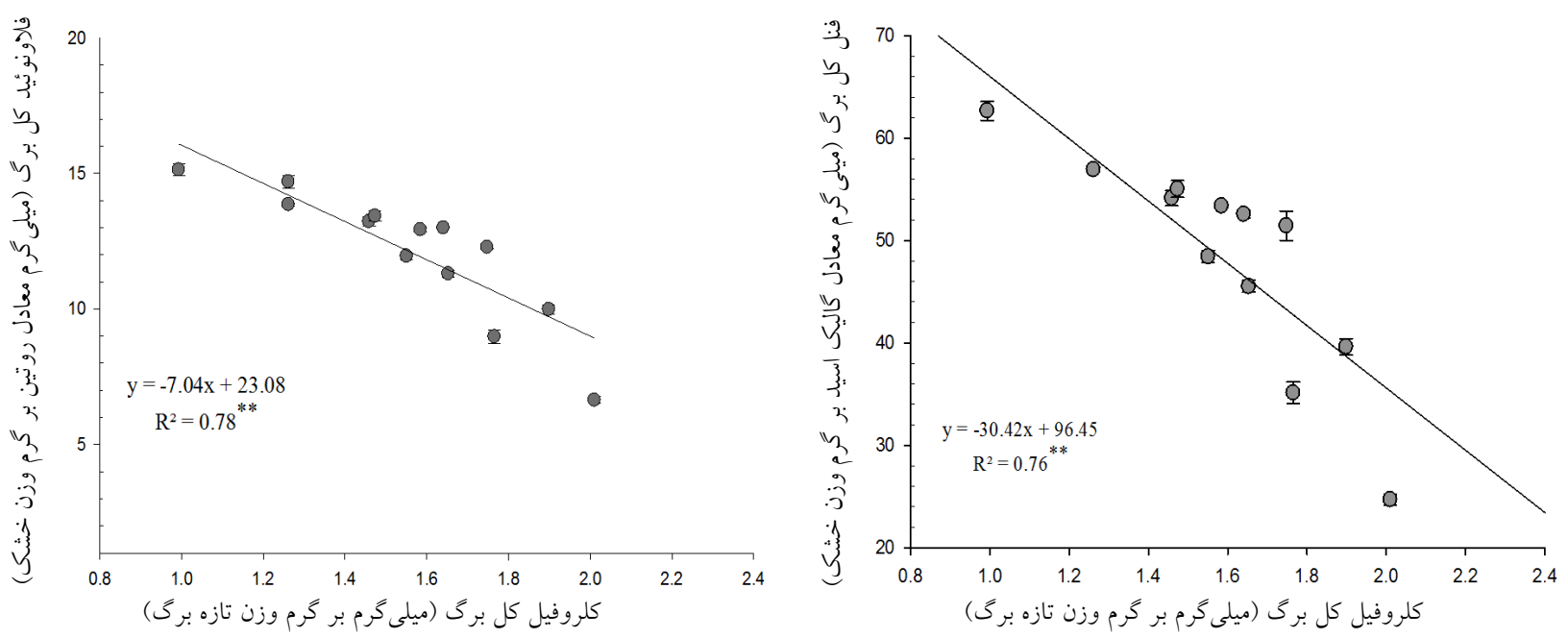

شكل V. همبستخى بين غلظت تركيبات فلاونوئيدى و فنولى و ميزان كلروفيل در برى كياه

علائم زردبركى و با كمتـرين غلظـت كلروفيـل داراى بيشترين غلظت تركيبات فنولى و فلاونوئيدى بوده است. افزايش غلظـت فئت

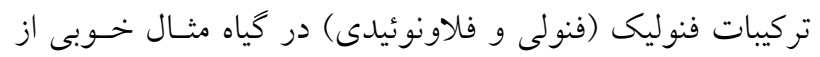

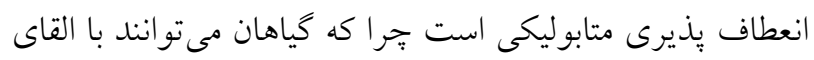

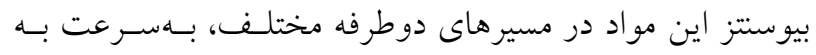

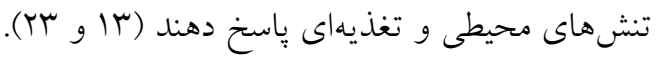

\section{نتيجه گيرى}

نتايج نشان داد، ياسخ كياه يونجه يكساله (اسكوتلاتا) به كمبود

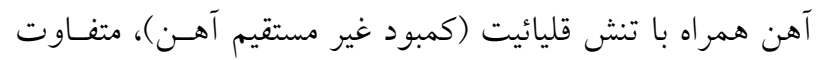

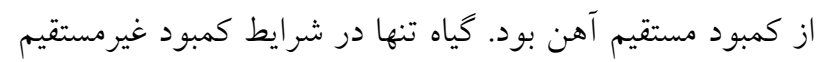
آهـن (IDC) علائسم زردبر كَى را نشـان داد كسه باعـث ايجـاد

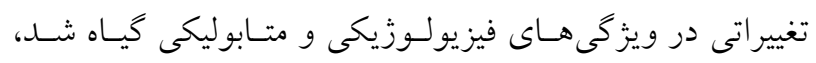

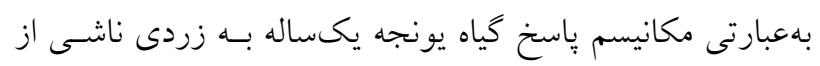

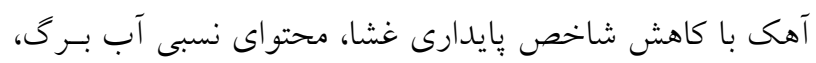

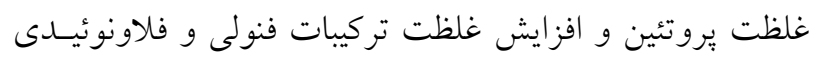

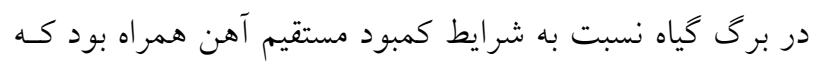

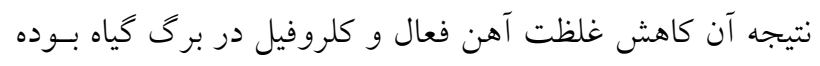

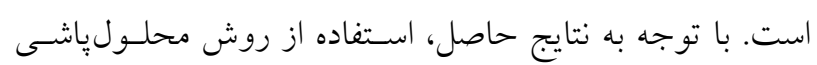

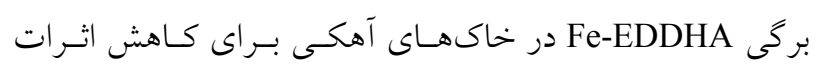

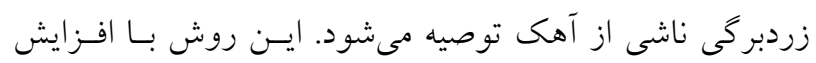

نتايج هسى و واترز نشـان داد كـه در شـرايط IDC ميـزان بيـان

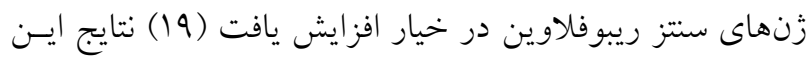

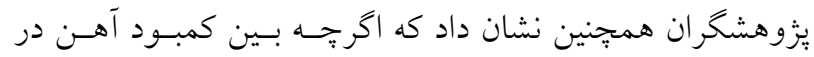

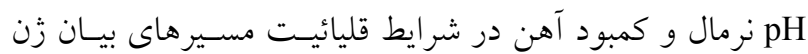
مشتركى وجود دارد و با يكديخر هم يوشانى دارنـــ امـا ايسن دو

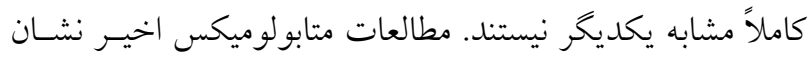

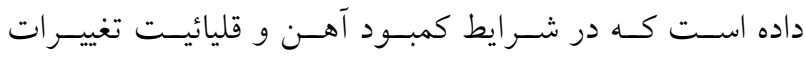

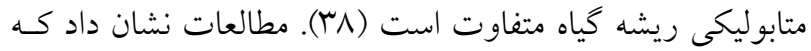

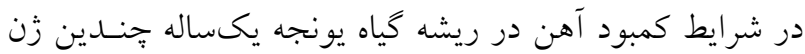

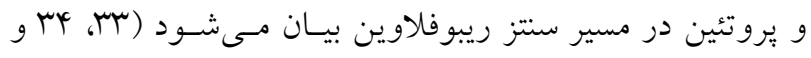

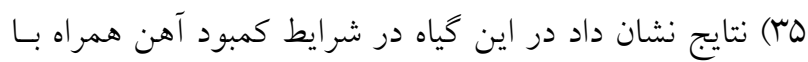

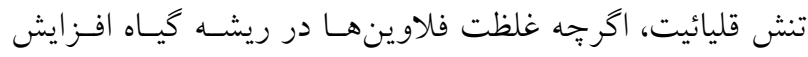

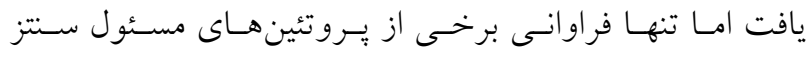

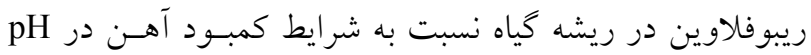
نرمال افزايش يافت (بس). ايسن در حسالى اسـت كـه در شـرايط

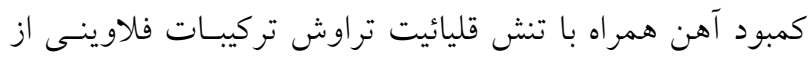

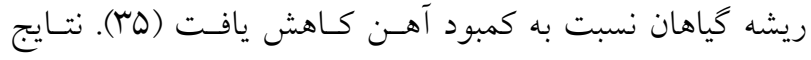
حاصل از مطالعات نشان داد كه بين غلظت كلروفيل و تركيبـات

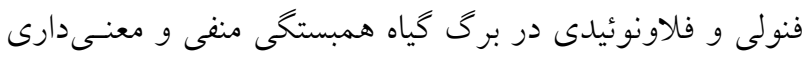

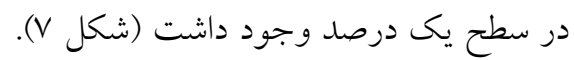

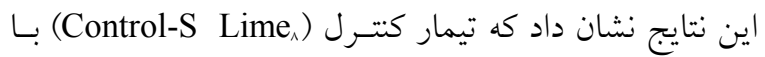




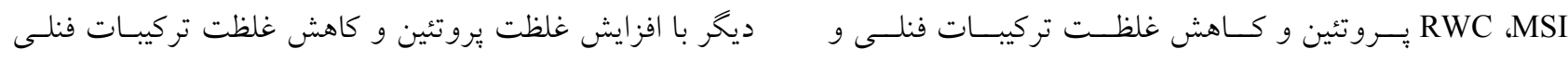

$$
\begin{aligned}
& \text { فلاونوئيدى برى نسبت به تيمار كنترل و مصرف خاكى آهن در و فلاونوئيدى موجب خوش خـوراكى و افـزايش ارزش غـذايى } \\
& \text { سطوح جهار و هشت درصد آهك، از يكسو موجـبـ افـزيش يونجه يكساله در شرايط كمبود آهن ناشى از حضور آهـى در }
\end{aligned}
$$

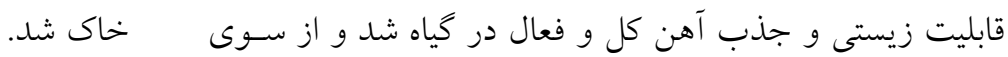

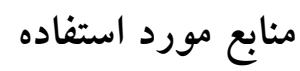

1. Abadía, J., S. Vázquez, R. Rellán-Álvarez, H. El-Jendoubi, A. Abadía, A. Álvarez-Fernández and A-F. López-Millán. 2011. Towards a knowledge-based correction of iron chlorosis. Plant Physiology and Biochemistry 49: 471-482.

2. Alford, C. M., J. M. Krall and S. D. Miller. 2003. Intercropping irrigated corn with annual legumes for fall forage in the high plains. Agronomy Journal 95:520-525.

3. Álvarez-Fernández, A., S. García-Marco and J. J. Lucena. 2005. Evaluation of synthetic iron (III)-chelates (EDDHA $/ \mathrm{Fe}^{3+}$, EDDHMA $/ \mathrm{Fe}^{3+}$ and the novel EDDHSA $/ \mathrm{Fe}^{3+}$ ) to correct iron chlorosis. European Journal of Agronomy 22:119-130.

4. Alvarez-Parrilla, E., L. A. De La Rosa, R. Amarowicz and F. Shahidi. 2011. Antioxidant activity of fresh and processed jalapeño and serrano peppers. Journal of Agricultural and Food Chemistry 59:163-173.

5. Arnon, D. I. 1949. Copper enzymes in isolated chloroplasts: phenol oxidase in Beta vulgaris. Plant Physiology 24:1-15.

6. Bradford, M. M. 1976. A rapid and sensitive method for the quantitation of microgram quantities of protein utilizing the principle of protein-dye binding. Analytical Biochemistry 72:248-254.

7. Briat, J. F., C. Curie and F. Gaymard. 2007. Iron utilization and metabolism in plants. Current Opinion in Plant Biology 10:276-282.

8. Castagna, A., S. Donnini, and A. Ranieri. 2009. Adaptation to iron-deficiency requires remodelling of plant metabolism: An insight in chloroplast biochemistry and functionality. pp. 205-212, In: Ashraf, M., M. Ozturk, H. Athar (Eds.), Salinity and Water Stress. Tasks for Vegetation Sciences, vol 44. Springer, Dordrecht.

9. Chebbi, M., N. Msilini, T. Amdouni and Z. Ouerghi. 2013. Differential responses of two lactuca sativa varieties to bicarbonate-induced iron deficiency. Journal of Stress Physiology \& Biochemistry 9: 39-52

10. Chen, H., Z. Hu, X. Li, F. Zhang, J. Chen and M. Zhang. 2016. Iron fertilizers applied to calcareous soil on the growth of peanut in a pot experiment. Archives of Agronomy and Soil Science 62:1753-1764.

11. Chun-xia, L., C. Tie, G. Hai-yan, H. Qing-fang, Z. Yu-zheng and D. Rui-xia. 2017. Effect of foliar ferrous sulphate application on alfalfa (Medicago sativa L.) leaf Fe content, photosynthetic capacity and yield. Nature Environment and Pollution Technology 15: 765-773.

12. Deshmukh, P., R. Sairam and D. Shukla. 1991. Measurement of ion leakage as a screening technique for drought resistance in wheat genotypes. Indian Journal of Plant Physiology 34:89-91.

13. Ferreira, J., M. Cornacchione, X. Liu and D. Suarez .2015. Nutrient composition, forage parameters, and antioxidant capacity of alfalfa (Medicago sativa L.) in response to saline irrigation water. Agriculture 5:577-597.

14. García-Mina, J. M., E. Bacaicoa, M. Fuentes and E. Casanova. 2013. Fine regulation of leaf iron use efficiency and iron root uptake under limited iron bioavailability. Plant Science 198:39-45.

15. Ghanavati, F., H. Mozaffari, A. Masoumi and S. Kazempour. 2007. Morphological studies of pollen grains of Medicago species in Iran. Iranian Journal of Crop Sciences 9: 136-145. (In Farsi).

16. Gruber, B and H. Kosegarten. 2002. Depressed growth of non chlorotic vine grown in calcareous soil is an iron deficiency symptom prior to leaf chlorosis. Journal of Plant Nutrition and Soil Science 165:111-117.

17. Hamouda, H. A., M. F. El-Dahshouri, M. O. Hafez and N. G. Zahran. 2015. Response of le conte pear performance, chlorophyll content and active iron to foliar application of different iron sources under the newly reclaimed soil conditions. International Journal of ChemTech Research 8:1446-1453

18. Hseu, Z. Y. 2004. Evaluating heavy metal contents in nine composts using four digestion methods. Bioresource Technology 5:53-9

19. Hsieh, E. J and B. M. Waters. 2016. Alkaline stress and iron deficiency regulate iron uptake and riboflavin synthesis gene expression differently in root and leaf tissue: Implications for iron deficiency chlorosis. Journal of Experimental Botany 67:5671-5685.

20. Katyal, J. C and B. D. Sharma. 1984. Some modification in the assay of $\mathrm{Fe}^{2+}$ in 1-10, o-phenanthroline extracts of fresh plant tissues. Plant and Soil 79:449-450.

21. Kosegarten, H and H. Koyro. 2001. Apoplastic accumulation of iron in the epidermis of maize (Zea mays) roots grown in calcareous soil. Physiologia Plantarum 113:515-522 
22. Kosegarten, H., B. Hoffmann, E. Rroco, F. Grolig, K. Gluesenkamp and K. Mengel. 2004. Apoplastic pH and FeIII reduction in young sunflower (Helianthus annuus) roots. Physiologia Plantarum 122:95-106.

23. Kallala, N., M. Wissal, K. Jelali, Z. Kais, H. Mhadhbi. 2018. Inoculation with efficient nitrogen fixing and indoleacetic acid producing bacterial microsymbiont enhance tolerance of the model legume Medicago truncatula to iron deficiency. BioMed Research International 2018:1-14.

24. Lindsay, W. L and W. A. Norvell. 1978. Development of a DTPA soil test for zinc, iron, manganese, and copper. Soil Science Society of America Journal 42:421-428.

25. López-Millán, A-F., F. Morales, A. Abadía and J. Abadía. 2001a. Iron deficiency associated changes in the composition of the leaf apoplastic fluid from field-grown pear (Pyrus communis L.) trees. Journal of Experimental Botany 52:1489-1498.

26. Masalha, J., H. Kosegarten, E. Omer and K. Mengel. 2000. The central role of microbial activity for iron acquisition in maize and sunflower. Biology and Fertility of Soils 30:433-439.

27. Medina-Juárez, L. Á., D. M. Molina-Quijada, C. L. Del Toro Sánchez, G. A. González-Aguilar and N. GámezMeza. 2012. Antioxidant activity of peppers (Capsicum annuum L.) extracts and characterization of their phenolic constituents. Interciencia Journal 37:588-593.

28. Menichini. F., R. Tundis, M. Bonesi, M. R. Loizzo, F. Conforti, G. Statti, B. De Cindio, P. J. Houghton and F. Menichini. 2009. The influence of fruit ripening on the phytochemical content and biological activity of Capsicum chinese Jacq. cv Habanero. Food Chemistry 114:553-560.

29. Msilini, N., H. Attia, M. Rabhi, N. Karray, M. Lachaâl and Z. Ouerghi. 2012. Responses of two lettuce cultivars to iron deficiency. Experimental Agriculture 48:523-535.

30. Noguchi, A., T. Yoshihara, A. Ichihara, S. Sugihara, M. Koshino, M. Kojima and Y. Masaoka .1994. Ferric phosphate-dissolving compound, alfafuran, from Alfalfa (Medicago sativa L.) in response to iron-deficiency stress. Bioscience, Biotechnology, and Biochemistry 58:2312-2313.

31. Osuagwu, G. G. E., H. O. Edeoga and A. N. Osuagwu. 2010. The influence of water stress (drought) on the mineral and vitamin potential of the leaves Ocimum gratissimum L. Recent Research in Science and Technology 2:27-33.

32. Robin, A., G. Vansuyt, P. Hinsinger, J. M. Meyer, J. F. Briat and P. Lemanceau. 2008. Iron dynamics in the rhizosphere: Consequences for plant health and nutrition. Advances in Agronomy 99:183-225.

33. Rodríguez-Celma, J., G. Lattanzio, M. A. Grusak, A. Abadía, J. Abadía and A-F. López-Millán. 2011. Root responses of Medicago truncatula plants grown in two different iron deficiency conditions: Changes in root protein profile and riboflavin biosynthesis. Journal of Proteome Research 10:2590-2601.

34. Rodriguez-Celma, J., W-D. Lin, G-M. Fu, J. Abadia, A-F. Lopez-Millan and W. Schmidt. 2013. Mutually exclusive alterations in secondary metabolism are critical for the uptake of insoluble iron compounds by Arabidopsis and Medicago truncatula. Plant Physiology 162:1473-1485.

35. Rodríguez-Celma, J., S. Vázquez-Reina, J. Orduna, A. Abadía, J. Abadía, A. Álvarez Fernández and A-F. LópezMillán. 2011b. Characterization of flavins in roots of Fe-deficient strategy I plants, with a focus on Medicago truncatula. Plant and Cell Physiology 6:45-52

36. Rombolà, A. D., Y. Gogorcena, A. Larbi, F. Morales, E. Balde, B. Marangoni, M. Tagliavini and J. Abadía. 2005. Iron deficiency-induced changes in carbon fixation and leaf elemental composition of sugar beet (Beta vulgaris). Plant and Soil 271:39-45

37. Schmid, N. B., R. F. H. Giehl, S. Doll, H-P. Mock, N. Strehmel, D. Scheel, X. Kong, R. C. Hider and N. V. Wiren. 2014. Feruloyl-CoA 6'-Hydroxylase1-dependent coumarins mediate iron acquisition from alkaline substrates in Arabidopsis. Plant Physiology 164: 160-172.

38. Tato, L., P. De Nisi, S. Donnini and G. Zocchi. 2013. Low iron availability and phenolic metabolism in a wild plant species (Parietaria judaica L.). Plant Physiology and Biochemistry 72: 145-153.

39. Vigani, G and G. Zocchi .2009. The fate and the role of mitochondria in Fe-deficient roots of strategy I plants. Plant Signaling and Behavior 4: 375-379.

40. Whetherley, P. E. 1950. Studies in water relations of cotton plants: I. The field measurement of water deficit in leaves. New Phytologist 49: 81- 87.

41. Yeh, D. M., L. Lin and C. J. Wright. 2000. Effects of mineral nutrient deficiencies on leaf development, visual symptoms and shoot-root ratio of Spathiphyllum. Scientia Horticulturae 86: 223-233. 


\title{
Comparison of Foliar and Soil Fe Fertilization on Medicago scutellata Physiological-Biochemical Characteristics and Active Iron in Soils Containing Different Amounts of Lime
}

\author{
Z. Gheshlaghi ${ }^{1}$, R. Khorassani ${ }^{\star}{ }^{*}$ M. Kafi ${ }^{3}$ and A. Fotovat ${ }^{4}$
}

(Received: November 5-2018; Accepted: February 27-2019)

\begin{abstract}
Reducing iron solubility in calcareous soils causes iron chlorosis symptoms in the plant. In order to investigate the response of $M$. scutellata to direct and indirect iron deficiency, a factorial experiment was conducted in a completely randomized design with three replications. The experimental factors included three levels of lime $(0,4$ and $8 \%)$ and five levels of $\mathrm{Fe}\left(0,5\right.$ and $10 \mathrm{mg} \mathrm{Fe} \mathrm{Kg} \mathrm{soil}{ }^{-1}$ as soil application and 0 and $2.1 \mu \mathrm{M} \mathrm{Fe}$ as foliar spray). Zero Fe concentrations in soil and foliar Fe fertilization was considered as control-S and control-F treatment, respectively. The results showed that the amendment of $8 \% \mathrm{CaCO}_{3}$ in control treatments caused typical Fe deficiency symptoms, including decreases in chlorophyll, total and extractable leaf Fe concentration, protein, leaf relative water content, membrane stability index and increases in leaf total phenolic and flavonoid concentration when compared to $0 \%$ lime. The soil and foliar Fe fertilisation led to the improvement of Fe chlorosis, increases in chlorophyll, Fe, protein, and decreases in concentration of phenolic compounds in three levels of lime. The foliar Fe fertilization in three levels of lime increased total and extractable leaf Fe content, compared to two soil Fe treatments, but foliar Fe fertilization (in 4 and $8 \%$ of lime) yielded progressively lower leaf phenolic compounds. The highest leaf chl concentration in $8 \%$ lime was observed in $10 \mathrm{mg} \mathrm{Fe} \mathrm{Kg} \mathrm{soil}{ }^{-1}$ and foliar Fe fertilization. The presented data indicate that the use of foliar application of $\mathrm{Fe}$ (Fe- EDDHA) is potent to reduce the effects of lime induced chlorosis in plants in calcareous soils.
\end{abstract}

Keywords: Calcium carbonate, Chlorosis, Fe-EDDHA, Phenolic and Flavonoids Compounds

1, 2, 4. PhD Graduate, Associate Professor and Professor, Respectively, Department of Soil Science, Faculty of Agriculture, Ferdowsi University of Mashhad, Mashhad, Iran.

3. Professor, Department of Agronomy, Faculty of Agriculture, Ferdowsi University of Mashhad, Mashhad, Iran.

*: Corresponding Author, Email: khorasani@um.ac.ir 